\title{
Expletive selection and CP arguments in Dutch
}

\author{
E. G. Ruys
}

Received: 5 February 2008 / Accepted: 8 July 2009/Published online: 25 June 2010

(C) The Author(s) 2010. This article is published with open access at Springerlink.com

\begin{abstract}
It has recently been claimed (Hazout 2004) that the English expletives it and there do not differ in their theta-properties. This paper argues that Dutch het and er do differ: all instances of het bear a (quasi-)theta-role; no instance of er does. Evidence comes from an analysis of expletive selection in constructions with seemtype verbs.
\end{abstract}

Keywords Expletive $\cdot$ Impersonal passive $\cdot$ Quasi-argument $\cdot$ Seem-verb

\section{Introduction}

Consider the pattern of expletive selection in (1).

(1) a. there / *it is a man (in the garden)

b. it / *there is cold (in the garden)

c. it / *there seems $\mathrm{CP}^{1}$

Why does the existential construction (1a) disallow the it-expletive, and why do weather-verb and seem-constructions (1b) and (1c) disallow the there-expletive?

One approach is to distinguish it and there in terms of Case- and theta-properties. For instance, Chomsky (1995) and later work argued that it has a full set of $\varphi$ features, including Case, but there does not. In addition, Chomsky (1981) and later work assumed that it sometimes, as in (1b), bears a (quasi-)theta-role, but there never does. It is not difficult to make these differences between it and there conspire to yield the pattern in (1), as discussed in more detail below.

In a recent paper, Hazout (2004) endorses an entirely different approach: the expletives there and it differ neither in their theta-properties, nor in their Case-

\footnotetext{
${ }^{1}$ In example sentences, I use CP to stand for some finite, closed-phase embedded CP.

E. G. Ruys $(\bowtie)$

UiL-OTS, Utrecht University, Trans 10, NL-3512 JK Utrecht, The Netherlands

e-mail: E.G.Ruys@uu.nl
} 
properties. Following Williams (1994), Hazout argues that both a man in (1a) and cold in (1b) are predicates, which take the expletives as their subjects, but without assigning them a theta-role. But if there is no Case- or theta-distinction between there and it, how can we account for the expletive selection facts?

Hazout attributes the distinction between (1a) and (1b) to an 'idiosyncratic' property of English: there subcategorizes for a predicate containing specified $\varphi$ features (those on man in (1a)), whereas it subcategorizes against such a predicate. Motivation for playing down the distinction between the two constructions comes from Hebrew, which supposedly uses the same covert expletive in both cases:

$$
\begin{aligned}
\text { a. pro haya } & \text { iš ba-gina } \\
\text { was } & \text { man in.the-garden } \\
\text { b. pro haya } & \text { kar ba-gina } \\
\text { was } & \text { cold in.the-garden }
\end{aligned}
$$

[Hebrew]

In the present paper, I want to argue that the expletives er and het which appear in the Dutch counterparts of (1) do show important differences. I will focus in particular on the theta-properties of these elements, and argue (contra Hazout) that, over and above any differences in Case- and $\varphi$-features, het always bears a theta-role (if only a quasi-theta-role), whereas er does not. The main argument will be based on the Dutch counterpart of the seem-construction (1c). Some Dutch seem-verbs require the it-expletive, while other verbs allow both the thereexpletive and the $i t$-expletive:

(3) a. het/*er schijnt $\mathrm{CP}$

it/there seems CP

[Dutch]

b. het/er blijkt $\mathrm{CP}$

it/there turns.out $\mathrm{CP}$

I will argue that expletive selection in these examples is determined by the thetaproperties of the verbs. I will concentrate on Dutch, and to a lesser degree on Danish and English. In other Germanic languages, distinguishing the it- and there-expletives is not straightforward, and more research is required to determine whether my conclusions extend to these languages. For the same reason, non-Germanic languages are outside the scope of this paper as well.

The remainder of the paper is organized as follows. Section 2 summarizes Reuland's (1983) argument for the theta-relatedness of het, which is based on Dutch impersonal passives; I show that this argument holds good only under certain specific assumptions on feature checking relations in impersonal passives. Section 3 introduces the expletive selection properties of different seem-type verbs in Dutch, which will provide the basis for the argument in the following sections. Section 4 discusses various previous accounts of it-expletives, including Bennis' (1986) analysis of the relevant seem-constructions, and argues that these accounts are insufficient. In subsequent sections, I propose an alternative, which requires het to bear a theta-role. Section 7 returns to impersonal passives and suggests that Dutch seem-constructions may support an analysis of feature checking relations in impersonal passives under which Reuland's argument from section 2 can be maintained. 


\section{Impersonal passives, weather-verbs, and default $\varphi$-valuation}

Before turning to my main argument, I want to explore an existing argument for the obligatory theta-marking of het-expletives, on the basis of Impersonal Passives (passives of unergative verbs). The present section assesses whether this argument, which appears in the literature in the GB-framework, can be upheld in a minimalist setting.

Before we can reconstruct the argument, we first need to address the question of feature checking in impersonal passive constructions. Consider the data in (4) (unless otherwise noted, all data are from Dutch or English):

(4) a. er wordt gedanst

there is-PASS danced

b. er wordt op Piet gerekend

there is-PASS on Piet counted

c. er wordt beweerd CP

there is-PASS claimed $\mathrm{CP}$

If we assume, following Chomsky (1995) and later work, that a finite T must check (value and delete) its uninterpretable nominal $\varphi$-features, and that this requirement can be met by the it-expletive but not by the $\varphi$-defective there-expletive, then the question arises how $\mathrm{T}$ checks its features in (4), where no nominal element appears to be present for T to agree with and assign NOM to. Let us assume for the moment that $\mathrm{T}$ in (4) is subject to a default rule, as stated in (5):

\section{(5) Default $\varphi$-valuation}

Dutch, Danish $(, \ldots)$ have a rule of default valuation $[3, \mathrm{sg}]$ and deletion of $\varphi$ on

T; English does not. ${ }^{2}$

This rule takes care of the technical problem raised by (4), while at the same time stating the cross-linguistic variation in our sample of languages, shown in (4), (6), and (7): the English impersonal passives in (7) crash on the undeleted, uninterpretable $\varphi$-features on $\mathrm{T}$.

(6) a. at der er blevet danset

Danish; Vikner (1995:209/210/243)

that there has-been-PASS danced

b. at der er blevet skudt på båden

that there has-been-PASS shot at the.boat

c. at der blev sagt CP

that there was-PASS said $\mathrm{CP}$

(7) a. * there was danced

b. * there was counted on Peter

c. * there was claimed $\mathrm{CP}$

Naturally, the default $\varphi$-feature valuation rule stipulated in (5) is only one of several ways in which we might deal with impersonal passives; I will discuss a

\footnotetext{
${ }^{2}$ In the framework adopted here, default $\varphi$-valuation will further entail absorption of Nominative Case (assignment of which is contingent on agreement between T and the subject; see, e.g., Chomsky 2000). This would serve to block (5) in constructions other than impersonals.
} 
possible alternative shortly. For now, my purpose is merely to set up a theoretical background which will allow us to reconstruct in a minimalist setting the GB-style argument for the theta-relatedness of the het-expletive.

Once we adopt the default rule (5), we can construct arguments to the effect that a Case-distinction between er and het does not suffice to describe their distribution; we need to assume in addition that het is theta-related. Consider first the weatherverb construction in $(8)^{3}$ :

(8) a. het regende

b. * er regende it / *there rained

One obvious way of blocking the er-expletive in this construction is along the lines of Chomsky $(1995,2000,2001)$. The it-expletive het in (8a) can receive Case and has the full set of $\varphi$-features necessary to value and delete those on $\mathrm{T}$. The there-expletive does not bear Case, and has an incomplete set of $\varphi$-features, hence cannot satisfy the requirements of $\mathrm{T}$. However, under the assumption that Dutch has rule (5), this rule should be able to delete the $\varphi$-features on $\mathrm{T}$ in $(8 \mathrm{~b})$. That leaves theta-theory as another obvious explanation: if weather verbs must assign a (quasi-)theta-role, as proposed in Chomsky $(1981,1986)$, and er cannot bear a theta-role, this will block (8b). The wellformedness of (8a) then supports the conclusion that het at least can bear a theta-role.

A stronger conclusion can be drawn from expletive selection in impersonal passives. ${ }^{4}$

$$
\begin{gathered}
\text { a. } * \text { het wordt gedanst } \\
\text { it is-PASS danced } \\
\text { b. } * \text { het wordt op Piet gerekend } \\
\text { it is-PASS on Piet counted }
\end{gathered}
$$

$$
\text { * it was danced / counted on Peter }
$$

Again, we can show that postulating a difference in Case- and $\varphi$-features between er and het is not enough to block (9) and (10). If the only distinction between the er and het expletives were the absence or presence of a full set of $\varphi$-features, and the corresponding ability to satisfy the $\varphi$-requirements of $\mathrm{T}$ (and need to receive Case), then it should be possible to license the het-expletive in impersonal passives (9), simply by not applying the default $\varphi$-feature valuation rule (which obviously has to be optional): then het should be allowed in (9) just as in weather-constructions. Moreover, if English disallows impersonal passives with there because it lacks rule (5), nothing should block an impersonal passive with the it-expletive, as in (10). And again, theta-theory provides an explanation: passive verbs do not assign an external theta-role, hence er is allowed as subject, but het is not: then the ill-formedness of (9) and (10) provides evidence that the het-expletive must bear a theta-role, and the

\footnotetext{
$\overline{3}$ Borrowing from Bolinger (1973), I will mostly refer to such constructions as 'ambience constructions' (also 'ambience verbs'), since 'weather verb' does not cover the full range of cases; see notes 5 and 30.

${ }^{4}$ The discussion below disregards passives with internal CP arguments, as in $(4 \mathrm{c})$. Although these are often regarded as impersonal passives, they are not passives of intransitives, and require a separate discussion, as the $\mathrm{CP}$ might potentially be involved in feature checking. I postpone discussion of this construction to Section 7 .
} 
er-expletive need not. This reconstructs the argument for the theta-relatedness of het from Reuland (1983) (see also Bennis 1986:109).

Moreover, Hazout's (2004) method of expletive selection (it subcategorizes for a predicate without $\varphi$-features; there for a predicate with $\varphi$-features) fails. It correctly predicts that het / it shows up with weather verbs, but it also predicts that het should occur with the impersonal passives in (4): the predicate does not appear to contain a nominal argument with $\varphi$-features. ${ }^{5}$

We now have an argument from impersonal passives that het requires a theta-role, but one that goes through only if (5) is the correct way of dealing with the Case/ Agreement requirements of $\mathrm{T}$ in this construction. I will outline one potential alternative manner of dealing with these checking requirements, which does not support an argument for the theta-relatedness of het.

Recall the influential GB-analysis of passives from Jaeggli (1986).

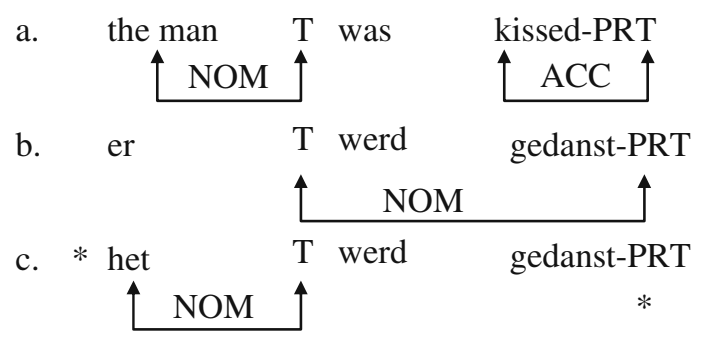

In an ordinary passive such as (11a), the verb assigns its external theta-role to the participial ending; in order to satisfy the visibility requirement, the ending is also assigned Accusative case. As a result, no Accusative is left for the internal argument, which therefore moves to Spec,IP to receive Nominative. A promising extension of this analysis to impersonal passives is the one in Roberts (1985): unergative verbs do not have accusative Case to assign, but Dutch Infl has the ability to assign Nominative to the participial ending, as in (11b); English Infl lacks this ability, blocking (7). Expletive selection can now come from case considerations alone: het in (11c) requires Case, but if het is assigned Nominative, no Case is left for the participial ending (or vice versa). This reasoning blocks het in impersonal passives without any assumptions on the theta-relatedness of het; if the analysis can be transposed to a minimalist framework, our argument for the theta-relatedness of het is seriously undermined.

\footnotetext{
5 The correct prediction for weather verbs does not extend, furthermore, to ambience constructions with nominal predicates. In the examples in (i), the there-expletive should be expected. The same may hold for (ii): assuming that the object has argumental status, it should contribute $\varphi$-features to the predicate in the same way a man does in (iib), on Hazout's analysis.
}

(i) het is winter / een koude winter / vrijdag / feest / groot feest / mijn verjaardag it is winter / a cold winter / Friday / celebration / big celebration / my birthday

(ii) a. het regende pijpestelen / klachten it rained cats.and.dogs / complaints

b. there appeared a man 
Let us see what a minimalist implementation might involve. Assume that the simultaneous absence of Accusative and external theta-role follows from whatever accounts for Burzio's generalization in the MP; say, the non-occurrence of the particular light verb $v$ (the $\mathrm{v}^{*}$ of Chomsky 2001) which assigns both (Chomsky 1995). The problem is in implementing the notion that Dutch $T$ assigns its Nominative case to the participial ending. What this means in the framework of Chomsky (2000), is that T can Agree with the participial ending (say, a functional head PRT), and that this relation suffices to value and delete the uninterpretable $\varphi$ features of $\mathrm{T}$, so that it will no longer assign Case. We must assume then that in Dutch (and Danish, but not in English) one variant of PRT has a full set of (uninterpretable) $\varphi$-features, valued to 3 rd person singular.

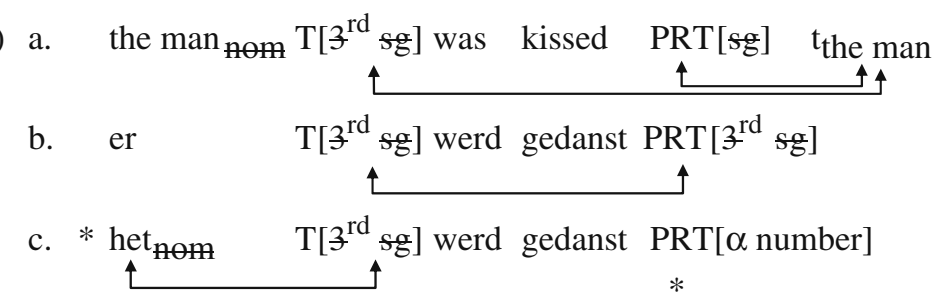

In a regular passive (see (12a)), we have a regular, defective PRT with just a number feature (and perhaps gender). PRT checks these features against the internal argument, but does not assign it Case; $\mathrm{T}$ subsequently agrees with the internal argument (whether it also agrees with PRT is irrelevant for our purposes; see Chomsky 2001, Frampton et.al. 2000 for some discussion), assigns it NOM, and has its $\varphi$-features valued and deleted. In impersonal passives (see (12b)), no internal argument is present for $\mathrm{T}$ to Agree with. However, in Dutch and Danish $\mathrm{T}$ as a probe can Agree with the non-defective PRT, and have its $\varphi$-features valued to 3 rd singular. We can now block the het-expletive in (12c) as follows. Since het has a full set of $\varphi$ features, T will Agree with het, assign it Nominative, have its features valued and deleted, and become inactive. This means that the PRT head cannot check its features: there is no internal argument for PRT to Agree with, and T already checks its features in assigning Nominative to het. The derivation crashes on the unchecked uninterpretable features on PRT. This is a fairly straightforward implementation of the GB-analysis in (11): het is blocked in impersonal passives because $\mathrm{T}$ cannot satisfy both het and PRT. ${ }^{6}$ No assumptions on the theta-relatedness of het are required.

\footnotetext{
${ }^{6}$ The analysis is not so easy to dismiss: as far as I can see it does not run afoul of any widely held assumptions. One problem, though, is that our Dutch/Danish PRT must have a person feature, whereas participles cross-linguistically do not show person morphology (thanks to Ora Matushansky for pointing this out to me). Another necessary assumption is that $\mathrm{T}$ cannot first check the features on defective PRT and then Agree with het: this will not happen if expletives are merged, not in Spec,TP as proposed by Chomsky (1995), but in spec, $v$ : then T will first find het. I feel this assumption is actually to be preferred, as it makes Chomsky's problematic assumption that the expletive probes $\mathrm{T}$, instead of $\mathrm{T}$ probing the expletive, unnecessary: see Section 6.2 below.
} 
In addition, note that on this analysis Hazout's $\varphi$-subcategorization approach to expletive selection can also deal with impersonal passives: er is selected because of the $\varphi$-features present on the passive participle. ${ }^{7}$

What the exercise in this section shows is that, as suggested in the literature, impersonal passives provide an argument that het needs a theta-role, but they do so only under specific assumptions on feature checking and Case-assignment. The argument would be strengthened if we could provide independent evidence that the default $\varphi$-valuation rule (5), and not an alternative such as sketched in (12), is the correct analysis of impersonal passives; we will return to this issue in Section 7. More importantly, it would be desirable to find evidence for the thetarelatedness of het that is independent of Case/Agreement considerations. I will argue that the data in the next section provide such evidence.

\section{Two types of $\mathrm{CP}$ selecting intransitives}

As discussed at length in Bennis (1986) (see also Koster 1987), Dutch intransitive verbs selecting $\mathrm{CP}$ arguments come in two variants:

\section{Dutch}

(13) a het schijnt $\mathrm{CP}$

it seems $\mathrm{CP}$

b. * er schijnt CP

there seems $\mathrm{CP}$

a. het blijkt $\mathrm{CP}$
it turns.out $\mathrm{CP}$

b. er blijkt $\mathrm{CP}$

there turns.out $\mathrm{CP}$

\section{English}

(15) a. it seems CP

b. * there seems $\mathrm{CP}$ non-existent:

(16) a.

it TURNs-OUT CP

b. there TURNs-OUT CP

\footnotetext{
${ }^{7}$ Another analysis of impersonal passives that can be made compatible with Hazout's approach to expletive selection is proposed by Mohr (2002): impersonal passives contain a covert cognate object (say a dance in (4a)): this can value $\varphi$ on T (and absorb NOM, again blocking the het-expletive without recourse to thetatheory), and provide the $\varphi$-features for the predicate required under Hazout's analysis. The main problem I see with Mohr's approach is that it does not extend to (4b), an impersonal passive where an internal, non-DP argument is present and the verb never allows an additional DP as an internal argument. Also, the contrast in (i) indicates a lack of evidence from control for the presence of an abstract cognate object:
}

(i) er werd * (een dans $\left.\mathrm{i}_{\mathrm{i}}\right)$ [zonder $\mathrm{PRO}_{\mathrm{i}}$ eerst ingestudeerd te zijn] gedanst 'there was (a dance) [without PRO first having been practiced] danced'

An anonymous reviewer proposes this variant of Mohr's analysis: impersonal passives (4), and the variant of (3b) with er, contain a covert het-expletive in addition to the er-expletive. The main conceptual problem with this option is that the existence of a covert expletive cannot easily be disproved or independently motivated (the hypothesis is immune, for instance, to the test in (i)). The main empirical problem is that it requires an explanation for why het cannot be overt in these structures: this would yield ill-formed (9) (or a variant of (9) with both er and het, equally ill-formed). (Conversely, additional assumptions are needed to block the covert version of het in ambience constructions and with schijnen verbs (see (3a))). Finally, the proposed structures with both er and covert het violate the Definiteness Restriction. 
The first category, exemplified by schijnen 'seem' in (13), selects het as a subject, and disallows the there-expletive, just like its English counterpart. The second category, exemplified by blijken 'turn out' in (14), allows both het and er. There is no such verb in English.

Several questions arise. First of all, if unvalued $\varphi$-features on T need to be valued and deleted, how is this accomplished in (14b), which contains no nominal argument and only the er-expletive? Secondly, what distinguishes languages like Dutch, which allow blijken-type verbs with one $\mathrm{CP}$ argument and an er-expletive, from languages like English, which do not? The answer I will suggest to these questions is, of course, that Dutch has the default $\varphi$-valuation rule (5), and English does not. I will discuss this in a little more detail in section 7.

The question that will be central to the discussion in this paper is the following. What distinguishes blijken-type verbs (which allow er) from schijnen-type verbs (which allow only het)? Given that Dutch permits the construction in (14b), with an internal CP argument and an er-expletive subject, what property could schijnen have that could prevent it from appearing in this construction? The answer, I will argue, is that schijnen assigns an external quasi-theta-role, which het can bear, but er cannot.

\section{Two theories of $i t$}

This section presents the empirical evidence that underlies my argument for the theta-relatedness of the it-expletive in Dutch seem constructions. As a point of departure, I outline two opposing views of the theta-properties of het / it expletives: those defended by Williams (1994) (and Postal and Pullum 1988) and by Bennis (1986). I will argue that neither proposal can deal successfully with the Dutch facts introduced in the previous section, and with some further properties of the blijken and schijnen type verbs that I will present.

Let us start by reviewing some contexts in which expletive it-elements may occur (for convenience, I will continue to refer to all these elements as 'itexpletives', even if I do not adopt the position that they are truly expletives, i.e. do not bear theta-roles):
a. it rained
b. I will wing it
c. I went for it

(18) a. I regret it $\mathrm{CP}$

b. I count on it $\mathrm{CP}$

c. I consider it deplorable CP

'unlinked' expletives

(19) a. it drives me nuts CP

b. it was regretted $\mathrm{CP}$

$$
\text { it seems CP }
$$

Firstly, there are it-expletives which occur by themselves, in the subject position of ambience constructions (17a) (see Bolinger 1973 for an inventory), and in the complement position of verbs or prepositions in various more or less idiomatic 
expressions (17b), (17c). Following Postal and Pullum (1988), I will refer to these as 'unlinked' expletives.

Secondly, there are it-expletives which co-occur with CPs; I will refer to all such cases as 'CP-linked' expletives. We can further distinguish, for presentational purposes, two classes of CP-linked expletives: ones that occupy apparent thetapositions, and ones that do not. The expletives in (18) occupy positions (the complement position of $\mathrm{V}$ and $\mathrm{P}$; the subject position of a small clause) that typically function as theta-positions, or positions of first merge. Furthermore, the theta-roles that these positions normally receive are in fact being assigned in these examples (and are semantically associated with the CPs co-occurring with the expletives: compare, e.g., (18b) with I count on Peter). It therefore seems initially plausible that these it-expletives are theta-marked. The subject-expletives in (19) are different in that they clearly do not occupy a theta-position; whether or not they originate in one remains to be seen. The seem-construction (20) which is our primary focus also falls into this category.

Various potential ways of dealing with CP-linked expletives have been proposed. One option is that all CP-linked expletives are true theta-less expletives (Williams 1994), as might seem initially plausible for (19) and (20). I argue in Section 4.1 that this approach fails to give us a handle on the schijnen / blijken contrast. Another option is that all CP-linked expletives receive regular theta-roles (Bennis 1986), as appears initially plausible for the cases in (18). This might provide a basis for analyzing the schijnen / blijken contrast (section 4.2), but I argue in Section 4.3 that it fails to explain the differences between cases like (19) and (20), and some additional differences between schijnen and blijken, which I will present. My proposal (Section 5) will be that, whereas all CP-linked expletives receive a theta-role, in some cases this is the quasi-role that is commonly attributed to the unlinked expletives in (17).

\subsection{Theory 1: all CP-linked expletives are true expletives}

At one end of the spectrum of potential analyses of CP-linked expletives we find the one advocated by Williams (1994:131ff), assumed also in Postal and Pullum (1988): all CP-linked expletives are true expletives, not bearing any kind of theta-role. Postal $\&$ Pullum propose several tests for detecting expletives: they do not bind emphatic anaphors, cannot function as subjects in tough-constructions, cannot coordinate, and cannot function as the of-complement of a nominalization. Postal \& Pullum claim that all CP-linked expletives uniformly pass these tests; in particular, the CP-linked expletives in (18), which appear in typically theta-marked positions, also qualify as expletives by these test. If so, no distinction between (18) on the one hand and (19), (20) on the other is necessary. ${ }^{8}$ This is not the place to examine Postal \& Pullum's

\footnotetext{
${ }^{8}$ Postal \& Pullum's position on whether expletives can be theta-marked is actually somewhat ambivalent. On the one hand, they state that a version of their argument will also go through if expletives are thetamarked, and that they assume that expletives are not theta-marked merely for the sake of argument, because it is so assumed in the theories they are attempting to disprove. They even provide an example of a CP-linked expletive which they suspect does receive a theta-role. However, when it comes to CP-linked expletives, it seems to me that their argument collapses if these bear a real theta-role, the one semantically associated with the linked CP: then their examples do not show that real expletives can occur in subcategorized positions.
} 
tests; I am interested here in determining whether an analysis such as this can deal with expletive selection in Dutch. ${ }^{9}$

Can we account for the expletive selection properties of schijnen and blijken type verbs, if all CP-linked expletives are real expletives? Theta-theory then cannot distinguish between het and er. One alternative is to rely on a distinction in Case $/ \varphi$-features. This works well enough for expletive selection in existential and weather-constructions:

(21) a. there / *it $\mathrm{T}_{\varphi}$ is [someone in the room]

b. it / *there $\mathrm{T}_{\varphi}$ is snowing

If it checks Case but there does not, it is blocked in (21a) as it would absorb the Case necessary for someone. If Case/ $\varphi$ on T must be checked, there is blocked in (21b).

How can this Case/ $\varphi$-based approach be extended to CP-linked expletives?
a. it / *there $\mathrm{T}_{\varphi}$ seems CP
b. it / *there $\mathrm{T}_{\varphi}$ was reported $\mathrm{CP}$

One option is that there is blocked in (22a) and (22b) because CP cannot check Case (see, e.g., Safir 1985). Another option is to postulate that English there requires a nominal associate (Chomsky 1981, 1991). Yet another option is that there subcategorizes for a predicate with $\varphi$-features (Hazout 2004). But none of these solutions can account for the contrast between (13) and (14) (repeated):

(13) het / *er schijnt CP

it $/ *$ there seems $\mathrm{CP}$

(14) het / er blijkt CP

it / there turns.out $\mathrm{CP}$

If $e r$ (or the $\mathrm{CP}$ ) manages to check Case and satisfy the requirements of $\mathrm{T}$ in (14), why does it fail to do so in (13)? Or if er fails to form a chain with the CP in (13), what does it form a chain with in (14)?

The simple fact appears to be that the constructions do not differ in any relevant way: they contain the same Case- and $\varphi$-features. One might attempt to introduce such a difference, which could be exploited by the Case/ $\varphi$-approach, by postulating that schijnen combines with a $\mathrm{T}$ that is not satisfied by er, and blijken combines with

\footnotetext{
${ }^{9}$ I see three problems with Postal \& Pullum's tests. Firstly, P\&P do not explain why it is that expletives pass these tests (the tests only constitute an 'informal syntactic diagnostic'), so that potentially, the tests might be for something else. For instance, idiom chunks also do not function as subjects of toughconstructions (*the shit is tough to prevent from hitting the fan; see Chomsky 1981:309); similarly, coordination is blocked also for weak or clitic pronouns that do receive theta-roles (Cardinaletti and Starke 1996). Secondly, other, equally plausible tests yield the opposite result; see the discussion of Bennis (1986) below. Finally, P\&P do not present the results of their tests for all categories distinguished here in (18) to (20); whether the results generalize, and how they can be extended to Dutch, remains to be seen. Embedding (18b) in a tough-construction in Dutch does not, e.g., appear impossible; cf. het is fijn om over te speculeren dat Jan de wedstrijd zou kunnen winnen it is nice to speculate about that J. might be able to win the match'.

Williams (1994:133) provides one additional test: CP-linked expletives are blocked in pseudo-passive *It was talked about that John had arrived (hence are not thematically related to the CP). But talk about also disfavors the CP-linked expletive in the active voice. Williams also argues that unlinked expletives must be considered not theta-marked, as this would explain, by Burzio's generalization, why weather verbs cannot be transitive; however, this appears to be factually incorrect: see footnote 30 , and (iia) in footnote 5 .
} 
a different $\mathrm{T}$ that is. However, raising variants of these and related examples show that it is the position of first merge of the expletive that fixes its choice, not the position where it checks its features. Schijnen allows an er subject, if it originates in a position that allows er; blijken blocks er if its position of first merge does:
a. het / er $\mathrm{T}_{\varphi}$ schijnt [IP $\mathrm{t}_{\text {expl }}$ te blijken $\mathrm{CP}$ ]
it / there seems to turn.out $\mathrm{CP}$
b. het $/ *_{\text {er }} \mathrm{T}_{\varphi}$ blijkt $\quad\left[\mathrm{IP} \mathrm{t}_{\text {expl }}\right.$ te schijnen $\mathrm{CP}$ ]
it / *there turns.out to seem $\mathrm{CP}$
c. het $/ *_{\text {er blijkt [IP }} \mathrm{t}_{\text {expl }}$ te regenen ]
it / *there turns.out to rain

I conclude that the Dutch expletive selection facts are not easily accounted for if all CP-linked het-expletives are like the er-expletive in not bearing a theta-role.

\subsection{Theory 2: CP-linked expletives are not expletives}

At the opposite end of the spectrum is Bennis (1986), who argues that the it-elements in (17)-(20) all bear a theta-role. This approach seems particularly appropriate, of course, for the CP-linked expletives in (18), repeated in (24) below, which appear to have been base-generated in theta-positions. The question of how the CPs come to be semantically associated with the theta-roles assigned to the linked expletives has received various answers in the literature. In Rosenbaum (1967), e.g., the CP is generated as a modifier of the NP headed by it and then extraposed. Bennis (1986) proposes that the CP is generated as an adjunct binding the pronoun; this makes the pronoun a regular Casemarked and theta-marked variable operator-bound by the CP. The details lie outside the scope of this paper, but I will assume below that some such method of transmitting the theta-role is possible. I will refer to a CP-linked expletive that receives and transmits a theta-role in this way as a 'CP-placeholder', and use co-superscripting as a theoryneutral notational device to indicate the relation, as shown in (24):

$$
\begin{aligned}
& \text { a. I regret }[\mathrm{DP}+\theta \text { it }]^{\mathrm{i}} \mathrm{CP}^{\mathrm{i}} \\
& \text { b. I count on }[\mathrm{DP}+\theta \text { it }]^{\mathrm{i}} \mathrm{CP}^{\mathrm{i}} \\
& \text { c. I consider }[\mathrm{DP}+\theta \text { it }]^{\mathrm{i}} \text { deplorable } \mathrm{CP}^{\mathrm{i}}
\end{aligned}
$$

CP-placeholders

According to Williams (1994), then, there exist no CP-placeholders; according to Bennis, all CP-linked expletives are CP-placeholders. Like Postal and Pullum (1988), Bennis presents some tests which, in his case, supposedly show that CPlinked expletives are arguments: they can control PRO; they can bind parasitic gaps; they can bind anaphors. ${ }^{10}$ Again, I shall not discuss these tests, but attempt to use the schijnen / blijken contrast as a new one. The question therefore is whether Bennis' approach can explain the Dutch expletive selection facts.

Bennis (1986) is in a better position than Williams (1994) to explain the schijnen / blijken contrast: the assumption that het-expletives, unlike er-expletives, function as arguments, provides an additional means of describing the differences in their

\footnotetext{
${ }^{10}$ Like Postal and Pullum (1988), Bennis does not demonstrate that all his tests yield the same result for all instances of it-expletives distinguished here (cf. footnote 9 above). For instance, Chomsky (1981:323f) showed that weather-it can control (it sometimes rains after PRO snowing) but claimed that the it-subject of seem cannot (on the other hand, Hornstein 1999, fn. 29, allows it seemed CP without PRO appearing CP).
} 
distribution. Bennis discusses the schijnen / blijken contrast at length. His analysis of the blijken-case (14) is as follows.
a. [IP $\operatorname{het}^{\mathrm{i}}\left[\right.$ vP blijkt $\left.\left.\mathrm{t}_{\text {het }}\right]\right] \mathrm{CP}^{\mathrm{i}}$ it turns.out $\mathrm{CP}$
b. [IP er [vP blijkt CP ]] there turns.out $\mathrm{CP}$

“blijken (cf. (14)) c-selects DP or CP”

Blijken has one internal, propositional theta-role to assign. In (25a), it assigns this role to a CP-placeholder, which subsequently moves to the subject position for Case; this yields the het-variant. Alternatively, blijken can assign its theta-role to a $\mathrm{CP}$ directly, as shown in (25b), in which case er is inserted to satisfy (Bennis' variant of) the EPP; this yields the er-variant. The analysis of the blijken / schijnen contrast I will propose in Section 5 below will follow Bennis' analysis for the blijken case given in (25). But I will not adopt Bennis' solution for the schijnen-case (13), given in (26):

$$
\begin{aligned}
& \text { a. [IP het } \left.{ }^{\mathrm{i}}\left[\mathrm{vP} \text { schijnt } t_{\text {het }}\right]\right] \mathrm{CP}^{\mathrm{i}} \text { "schijnen (cf. (13)) c-selects only DP" } \\
& \text { it } \quad \text { seems } \mathrm{CP} \\
& \text { b. * [IP er [vP schijnt CP ]] } \\
& \text { there seems CP }
\end{aligned}
$$

The het-variant (26a) receives the same analysis as the het-variant with blijken: het is again a CP-placeholder. Bennis blocks the er-variant in (26b) by assuming that schijnen subcategorizes for a DP-complement; therefore, only the derivation with the CP-placeholder pronoun is allowed. Clearly, the appeal to subcategorization is not available in a Postal \& Pullum type approach, which has to treat the CP itself as the argument in every case.

In the next section, I will discuss a major problem attending Bennis' proposal; here, I want to make some initial observations that shed doubt on his analysis of the Dutch expletive selection facts.

First of all, Bennis must treat both schijnen and blijken as ergative verbs that assign one, internal theta-role. Ergativity tests (see in particular Hoekstra 1984:176ff) do not apply easily to these verbs; but as far as can be determined, blijken is indeed ergative, but verbs of the schijnen category (which includes lijken/ geleken, in (28),(30)) are not:

$$
\begin{array}{ll}
\text { het is gebleken } & \mathrm{CP} \\
\text { it is-PERF turned.out } & \mathrm{CP}
\end{array}
$$

a. het heeft geleken [CP alsof ...]

$$
\text { it has-PERF seemed as if ... }
$$

b. het heeft erop geleken CP

it has-PERF like.it seemed $\mathrm{CP}$

c. Jan heeft altijd dom geleken

J. has-PERF always stupid seemed

(29) a. de gebleken feiten

the turned.out facts

b. het mooi gebleken boek the beautiful turned.out book 
(30) a. * de geleken feiten the seemed facts

b. * het mooi geleken boek / * [DP the beautiful seemed book]

Blijken takes the be-auxiliary zijn in the perfect tense in (27); those schijnen-type verbs that can appear in the perfect tense take the have-auxiliary hebben; see (28). ${ }^{11}$ Furthermore, the past participle of blijken can be used as a prenominal modifier, either by itself (29) or when selecting a small clause; the past participles of schijnenclass verbs cannot; see (30). ${ }^{12}$ These tests are far from conclusive; but at the very least, ergativity of the schijnen-class would be hard to prove.

Clearer evidence exists against Bennis' claim that the schijnen-variant subcategorizes for DPs, and against CPs. Some observations seem to confirm it:

(31) a. CP blijkt $t_{\mathrm{CP}}$ nu wel

CP turns.out now truly

b. * $\mathrm{CP}$ schijnt $\mathrm{t}_{\mathrm{CP}}$ nu wel

CP seems now truly

c. ${ }^{*} \mathrm{CP}$ seems to many people

Blijken in (31a) allows its CP argument to appear itself as preverbal subject, without an expletive. Schijnen in (31b) and its English counterpart in (31c) do not allow this. This is as predicted, if schijnen can assign its theta-role only to a DP.

However, when we attempt to combine these verbs with DP arguments, a different pattern emerges. While blijken can take a DP argument, which can move to subject position or remain VP-internal, the corresponding constructions with schijnen are ill-formed:

(32) a. zijn onschuld is gebleken

his innocence is turned.out

'he has turned out to be innocent'

b. er zijn geen tekortkomingen gebleken

there are no flaws turned.out

'no flaws have turned up'

c. * zijn onschuld schijnt

his innocence seems

d. * er schijnen geen tekortkomingen

there seem no flaws

\footnotetext{
${ }^{11}$ This test is far from uncontroversial. It has been argued, in particular by Zaenen (1993), that auxiliary selection is determined by telicity, not by ergativity; this would also describe the facts in (27) and (28): blijken is telic, the schijnen-verbs are atelic. However, the claim that all and only telic verbs take be is not correct: many (presumably unergative) telic verbs (e.g., zegevieren 'win') take have. Still, one could maintain that only telic verbs take be; e.g., Hoekstra and Mulder (1990) proposed that all and only telic ergative verbs take be; this gives the correct auxiliary selection in (27)/ (28) even if all blijken and schijnen verbs are ergative, as in Bennis' analysis. See however (51d) below for an atelic ergative verb taking be.

${ }^{12}$ It would be hard, however, to maintain that (30b) is due to unergativity of lijken, since we are dealing with the raising-variant.
} 
It appears as though schijnen c-selects against DPs, rather than for them. Bennis suggests that (32c), (32d) are blocked because schijnen, unlike blijken, only assigns a propositional theta-role. However, other verbs that strictly require propositional arguments (e.g., zeggen 'say') allow a broad range of DP-arguments (this, that, something, the same, etc.): all these are blocked with schijnen, as they are with English seem. Bennis (1986:115) provides only two examples of DP-arguments with schijnen-verbs:

$$
\begin{aligned}
& \text { dat lijkt me ook } \\
& \text { that seems to.me too }
\end{aligned}
$$

b. ?? het schijnt

$$
\text { it seems }
$$

I find these examples unconvincing. (33b) is ill-formed to me (at best, it's elliptical for het schijnt zo 'it seems thus', where schijnt selects a small clause). (33a) is a fixed expression; almost any other DP is disallowed. Another choice of schijnenverb also leads to ill-formedness in (33): the constructions are not productive. ${ }^{13}$ In the next section, we will explore several constructions which freely and productively allow DPs to stand in for propositions, and find that they cannot do so with schijnenverbs. I will argue that Bennis' claim that all CP-linked expletives are CPplaceholders cannot be maintained in view of the schijnen / blijken contrast. ${ }^{14}$

\footnotetext{
13 See Section 6.1 for discussion of Slifting, a construction which allows the CP argument to be suppressed, leading to wellformed examples that contain the string (33b).

${ }^{14}$ There is one other analysis of the schijnen / blijken contrast in the literature. Vikner (1995), following Moro (1997), proposes that schijnen verbs always select a Small Clause, with the CP as subject and het as the predicate which undergoes raising to subject, as shown in (ia) and (ib) (whereas blijken can also select an internal $\mathrm{CP}$ argument and then allows $e r$ in the subject position):
}

(i) a. it seems $\left[\mathrm{sC}_{\mathrm{SC}} \mathrm{t}_{\text {it }}\right]$

b. het schijnt [sC $\left.\mathrm{CP} t_{\text {het }}\right]$

c. * de waarheid $\mathrm{i}_{\mathrm{i}}$ schijnt [SC CP $\mathrm{t}_{\mathrm{i}}$ ] the truth seems $\mathrm{CP}$

d. * het blijft $\mathrm{CP}$

it remains $\mathrm{CP}$

However, this approach predicts that other NP/DP predicates should also be allowed in the subject position of seem CP, contrary to fact (see (ic)), and that het should also appear as a raised predicate with other verbs that select Small Clauses, such as blijven 'remain', also contrary to fact (see (id)). Another problem is the obligatoriness of predicate raising in (ia), (ib). For further arguments against Moro's approach, and comparison with Hazout (2004)/Williams (1994), see Hartmann (2005) and references cited there.

An anonymous reviewer proposes this variant of Moro's and Vikner's analysis: schijnen selects a Small Clause; het is the CP-placeholder subject of the SC; the predicate is a deleted zo 'thus' or zo te zijn 'to be thus'. This blocks the er-expletive because (for unknown reasons) er is blocked with small clauses with $z o$ (not with some other adjectives). There is, however, no independent evidence for the presence of this hidden predicate. On the contrary: there are verbs that select Small Clauses with CP-placeholder subject and $z o$-predicate, but they disallow deletion of $z o$ :

(ii) het blijft / wordt *(zo) CP

it remains / becomes so $\mathrm{CP}$

Secondly, the analysis presupposes that het with schijnen is a CP-placeholder, and predicts it should behave accordingly; in the next section I argue that this is not the case (see note 18 for the reviewer's position on this). 


\subsection{Two classes of CP-linked expletives}

What the two approaches to CP-linked het-expletives discussed in the preceding sections have in common, is that they treat all such expletives alike: for Williams (1994), all CP-linked expletives are real expletives; for Bennis (1986), all CP-linked expletives are CP-placeholders. This section discusses four constructions in which not all CP-linked expletives behave alike. In subsequent sections, I will propose an alternative analysis which takes this non-uniformity among CP-linked expletives into account.

The first construction that differentiates among CP-linked expletives is the pseudo-clefting construction. Consider first the it-expletives in (18), which occupy apparent theta-positions, hence are particularly susceptible to an analysis as CP-placeholders. These are in free variation with the pseudo-clefting operator:

(34) a. what I regret $t_{\text {what }}$ is $\mathrm{CP}$

b. what I'm counting on $t_{w h a t}$ is $\mathrm{CP}$

c. what I consider $t_{\text {what }}$ deplorable is $\mathrm{CP}$

This is hardly surprising: if a DP functioning as CP-placeholder can satisfy the relevant Case-, theta-, and c-selection requirements in these positions, then a DP whtrace should do so as well. In fact, what we are really testing for is whether a DP with a propositional interpretation is allowed in these positions. For the same reason, relativization is equally allowed here ${ }^{15}$ :

(35) CP, which I regret

When we apply this test to CP-linked expletives in subject position (the cases in (19) and (20)), we find that their behavior is not uniform. The examples in (19) allow pseudo-clefting and relativization as well:

(36) a. what $t_{\text {what }}$ drives me nuts is $\mathrm{CP}$

b. what $t_{\text {what }}$ was regretted $t_{\text {what }}$ was $C P$

But the it-expletive with seem-verbs cannot be replaced with a wh-trace (the observation is due to Bresnan 1972:136):

(37) a. * what seems is CP

b. * what appears is CP

c. * $\mathrm{CP}$, which appears to me

What this shows is that not all positions in which CP-linked expletives appear should be treated alike. If the expletives in (18) and (19) are indeed CPplaceholders, as seems plausible, then the it-expletive with seem verbs must be something else: a true expletive, or a quasi-argument. For if seem could combine with a CP-placeholder (a DP bearing Case and a propositional theta-role), how could (37) possibly be blocked?

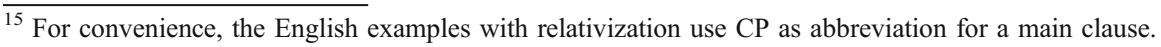


Turning to Dutch, we find the same pattern. The Dutch counterparts of (18) and (19) also allow pseudo-clefting (and relativization):

(38) a. wat $\mathrm{ik} \mathrm{t}_{\mathrm{wat}}$ betreur is $\mathrm{CP}$ what I regret is $\mathrm{CP}$

b. waar $\mathrm{ik}\left[\mathrm{PP}_{\mathrm{waar}}\right.$ op] reken is $\mathrm{CP}$ what I on count is $\mathrm{CP}$

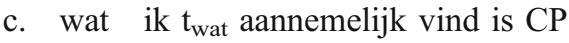
what I plausible find is $\mathrm{CP}$

(39) a. wat mij verbaasde was $\mathrm{CP}$ what me surprised was $\mathrm{CP}$

b. wat betreurd wordt is CP what regretted is-PASS is $\mathrm{CP}$

But when we apply this test to the schijnen and blijken verbs, we discover a difference between the two verb types:
a. * wat (er) schijnt is CP what (there) seems is $\mathrm{CP}$
b. * CP, wat (er) schijnt, ... 'CP, which (there) seems, ...'
c. wat (er) blijkt is $\mathrm{CP}$ what (there) turns.out is $\mathrm{CP}$
d. CP, wat gebleken is, ... CP, which turned.out is-PERF, ...

Like its English counterpart, schijnen does not allow pseudo-clefting or relativization on its subject position; but blijken does. It follows that Bennis' (1986) analysis described in Section 4.2 must be wrong, as it treats the CP-linked expletives with both verb classes uniformly as CP-placeholders. The fact that schijnen-verbs cannot take $w h$-traces as arguments strongly suggests that they should not be able to take CP-placeholders either. It follows that the it-expletive with schijnen must be something else: a true expletive, or a quasi-argument. Furthermore, Bennis's claim that schijnen-verbs subcategorize for DPs seems falsified: the facts in (40), like those in (32) above, rather suggest the reverse.

An approach along the lines of Williams (1994) and Postal and Pullum (1988), which does not postulate CP-placeholders with seem-type verbs (or anywhere else), might still be made to work, if certain stipulations are allowed. For subject positions which allow both it-expletives and wh-traces (the subject position of was regretted or blijken) one may suppose that the wh-trace reaches it by A-movement while the expletive is merged in it. For non-subject positions that allow both it-expletives and wh-traces (the object position of regret), one must suppose that the position is optionally theta-marked. Finally, when a subject position allows only the expletive, not the wh-trace (the subject position of schijnen / seem), one must somehow prevent a wh-trace from moving there; e.g., by postulating that seem c-selects against DP arguments: this will block (37). This also allows a description of the schijnen / blijken contrast in (40); but the expletive selection properties of these verbs described in Section 3 remain out of reach. 
A second test that distinguishes among different CP-linked expletive positions involves right-dislocation. CPs in right-dislocation, associated with a pronominal in argument position, can be distinguished by intonation from CPs associated with a CP-linked expletive:

(41) a. I like him, DP

b. I said it, CP

c. I regret it, $\mathrm{CP}$

d. I regret it $\mathrm{CP}$

The right-dislocation structure, also allowed with DPs (41a) and other categories, and with verbs that resist CP-linked expletives (41b), requires a 'comma-intonation,' involving at least an Intonational Phrase boundary. Thus we have both (41c) with a $\mathrm{CP}$ in right-dislocation and (41d) with a CP-linked expletive. We can now construct the minimal pairs in (42):

(42) a. it seems CP

b. * it seems, CP

c. it is believed CP

d. it is believed, $\mathrm{CP}$

The ill-formedness of (42b) strongly suggests that seem cannot take just a DP argument. This entails that the CP-linked expletive in (42a) cannot be a CPplaceholder (if it were, we would be forced to assume that seem can take a DPargument, but only if it somehow 'transmits' its theta-role to a CP; it is implausible that a verb could impose such a requirement on its argument). Consider now the Dutch pattern:
a. het lijkt CP
b. * het lijkt, CP
c. het blijkt CP
d. het is gebleken / ? blijkt, CP

We find the same pattern as before: the schijnen verb in $(43 \mathrm{a}, \mathrm{b})$ does not behave like the blijken verb in $(43 \mathrm{c}, \mathrm{d})$; Bennis' uniform treatment of the two verb types must be on the wrong track. ${ }^{16}$ The ill-formedness of rightdislocation with schijnen verbs suggests that the CP-linked expletive with these verbs is not a CP-placeholder, hence must be something else: a real expletive, or a quasi-argument.

A related test makes use of focusing. If a CP-linked expletive is a CPplaceholder, an argument bearing a theta-role, one expects that it should be possible to place it in focus, provided that the expletive pronoun is replaced with a variant that allows stress. ${ }^{17}$ We expect the same for a pronominal associated with

\footnotetext{
${ }^{16}$ Many speakers find constructions with the verb blijken (somewhat) marked in the present tense, and prefer the perfect tense. This does not, however, hold for all verbs in this class (e.g., opvallen 'strike').

${ }^{17}$ Het is a weak pronoun and cannot be stressed or contrastively topicalized on any usage; the strong (demonstrative) variants dit and hier in (44), (45) (not allowed on the quasi-argument usage) can be stressed (and topicalized: hier reken ik wel op, CP 'here I count PART on, CP'). It is not clear whether the strong variants can be CP-placeholders; perhaps these examples all involve right-dislocation.
} 
a $\mathrm{CP}$ in right-dislocation. We can facilitate the test by associating the pronominal with a focus-particle. This is allowed with typical CP-placeholders:

(44) a. Ik betreur alleen dit CP

I regret only this $\mathrm{CP}$

b. Ik reken alleen hier op CP

I count only this $s_{[+\mathrm{R}]}$ on $\mathrm{CP}$

c. I vind alleen dit aannemelijk $\mathrm{CP}$

I find only this plausible $\mathrm{CP}$

Focusing is allowed as well for those subject expletives that behave like CPplaceholders for the earlier tests:

(45) a. alleen dit verbaasde mij maar CP

only this surprised me PART $\mathrm{CP}$

b. alleen dit werd betreurd CP

only this was-PASs regretted $\mathrm{CP}$

As (44) and (45) show, focusing is allowed in the same constructions that allow clefting and relativization. The same possibility exists in right-dislocation structures:

(46) a. Ik zag alleen dit, het nieuwe huis van Jan

'I saw only this, John's new house.'

b. Ik vroeg alleen dit, of Jan een nieuw huis ging kopen

'I asked only this, whether John would buy a new house.'

I see no reliable way of determining whether the examples in (44) and (45) involve CP-linked expletives or right-dislocation: the intonational distinction is blurred in the context of focusing. But the contrast in (47) shows that both analyses must be blocked with schijnen verbs, which, unlike blijken-verbs, do not allow focusing:
a. alleen dit is maar gebleken $\mathrm{CP}$
only this is-PERF PART turned.out $\mathrm{CP}$
b. * alleen dit schijnt maar, CP
only this seems PART CP
c. * dat alleen dit mij maar toeschijnt $\mathrm{CP}$
that only this me PART seems $\mathrm{CP}$
'that only this seems to me CP'

I conclude again that the CP-linked expletive subject of seem-verbs cannot be a CP-placeholder, unlike the subject of blijken verbs.

In summary, we have inspected four contexts in which DPs bearing a propositional theta-role are freely allowed: pseudo-clefting, relativization, rightdislocation of CP, and focusing. We have seen that Dutch blijken allows such a propositional DP as its subject. But we have also seen that schijnen and seem do not allow such a propositional DP-argument. It follows that the het/it subject of schijnen and seem does not bear a propositional role (is not a CP-placeholder). It must be something else: a true expletive, or a quasi-argument. I conclude that Bennis' uniform treatment of all CP-linked expletives as CP-placeholders fails. And since we had already decided in the previous section that the het-expletive with schijnen must 
also not be treated as a pure expletive, we are now left with only one option: that it is a quasi-argument. I will take this up in the next section. ${ }^{18}$

\section{Deriving the schijnen / blijken contrast}

Table 1 summarizes the differences (seen so far) between the two verb classes. I propose that we can derive these facts by means of the following assumption ${ }^{19}$ :

(48) The het-expletive must bear a theta-role, the er-expletive cannot.

In combination with the selectional properties of the blijken and schijnen verbs, this assumption yields the following patterns.

(49) blijken: ergative, internal DP or CP argument
a. DP blijkt $t_{D P}$
b. er blijkt DP
c. wat (er) blijkt $\mathrm{t}_{\mathrm{wat}}$ is $\mathrm{CP}$
d. het ${ }^{\mathrm{i}}$ blijkt $\mathrm{t}_{\text {het }} \mathrm{CP}^{\mathrm{i}}$
e. er blijkt $\mathrm{CP}$
f. $\quad$ CP blijkt $t_{\mathrm{CP}}$

Blijken assigns one internal theta-role. This theta-role may be assigned to a DP, which may then move to Spec,TP (49a) or remain in situ, with an er expletive inserted for EPP (49b). As a special case, the argument DP may be a wh-operator in a pseudo-clefting (49c) or relativization construction; this operator may also undergo A-movement itself, or er may be inserted. In another special case, the DP is a CPplaceholder (49d), which moves to Spec,TP (the Definiteness Restriction rules out insertion of an er-expletive here). Alternatively, the internal theta-role may be assigned to a CP, in which case EPP may again be satisfied by an er-expletive (49e) or by the CP itself (49f). ${ }^{20}$ The right-dislocation example (43d) and the focusing example (47a) fall out as special cases of (49a).

\footnotetext{
${ }^{18}$ An anonymous reviewer proposes a different account of the properties of schijnen-verbs discussed in this section. Het with these verbs is a CP-placeholder, but the verbs are semantically not 'rich' enough to function as predicates by themselves; this blocks, e.g., (40a), (40b), (43b), (47b). However, in the absence of a theory of such semantic deficiency, and a method of measuring semantic richness, I feel this hypothesis is as yet insufficiently specific. As it stands, it does not seem to explain why blijken behaves differently, and why adding modifiers (or coordinated verbs) to a VP with a schijnen-verb does not improve the relevant structures $\left({ }^{*}\right.$ wat $t$ tegenwoordig wel degelijk schijnt is $C P$ 'what nowadays quite surely seems is CP'), while having a CP linked to the CP-placeholder does (as in (3a)).

${ }^{19}$ (48) is not intended as an exhaustive statement of the differences between $\mathrm{er}$ and het. It is likely that they also differ in Case- and $\varphi$-features. My argument here is that, over and above any difference in Case and $\varphi$-features, er and het must minimally differ also in their theta-properties. See note 32 for a brief discussion of the option that $e r$ does check Case.

${ }^{20}$ Another analysis for (49f) is that the argument is a covert DP, associated with a topicalized CP, as in Koster (1978).
} 
Table 1 Two types of verbs

\begin{tabular}{ll}
\hline Blijken & Schijnen / seem \\
\hline er and het & only het / it \\
pseudo-clefting, relativization, right-dislocation, & $\begin{array}{l}\text { no pseudo-clefting, relativization, right-dislocation, } \\
\text { focusing }\end{array}$ \\
focusing & no CP in subject-position \\
ergative & unergative
\end{tabular}

(50) schijnen / seem: quasi-transitive, internal CP argument, external quasi-argument
a. het schijnt $\mathrm{CP}$
b. * er schijnt CP
c. * het schijnt DP
d. * DP schijnt $t_{D P}$
e. * CP schijnt $\mathrm{t}_{\mathrm{CP}}$

(including pseudo-clefting, with DP $=\mathrm{t}_{\mathrm{wh}}$ ) (including pseudo-clefting, with DP $=\mathrm{t}_{\mathrm{wh}}$ )

Now consider the schijnen verb in (50a) with a CP-linked het-expletive subject. We have determined in the previous section that this het-expletive cannot be analyzed as a CP-placeholder. But it also cannot be analyzed as a pure expletive: our discussion of Williams (1994) and Postal and Pullum (1988) in Section 4.1 has led us to conclude that this would not provide a basis for distinguishing the hetexpletive from the er-expletive in such a way as to block er from appearing with this verb in (50b). This leaves us with the third option: the it-expletive is the quasiargument that also appears with weather verbs; schijnen assigns both an internal propositional role and an external quasi-theta-role. ${ }^{21}$

We can now derive the properties of the schijnen class as follows. (50a) with het-expletive allows both theta-roles to be assigned; (50b) is blocked because er cannot bear a theta-role. The occurrence of a DP internal argument can be blocked in several ways. One option is that schijnen c-selects against DPs; another option is that schijnen does not assign Accusative (the traditional assumption; see, e.g., Safir 1985:72). The data considered here provide no grounds for deciding between these options. Both options block (50c), as well as (50d). On the first option, the internal DP-argument is blocked at first merge in both examples. On the second option, the internal DP argument violates the Case filter in (50c), because het absorbs Nominative; but omitting het, as in $(50 \mathrm{~d})$, is not a solution, since this yields a theta-theory violation. Absence of relativization and pseudo-clefting, and absence of right-dislocation and focusing fall out as special cases. (50e) with the $\mathrm{CP}$ in subject position is also blocked by theta-theory, and perhaps by c-selection on Koster's (1978) account. Finally, we derive the fact that schijnen does not behave

\footnotetext{
${ }^{21}$ The idea is not entirely new: Safir (1985:356:footnote 65) suggests, in view of (50b), that "[p]erhaps, the expletive subject of seem in some languages is a quasi-argument." For Safir, the alternative analysis as a CP-placeholder was not an option. Schwartz (1972:70) on the other hand proposed that it in English it seems $\mathrm{CP}$ is also the it of ambience constructions.
} 
as an ergative verb; it is in fact a quasi-transitive one. I will return to some technical issues involved in this analysis in section $6.2 .^{22}$

Several predictions follow. First, since the appearance of the er-expletive is conditional only on the absence of an external theta-role (recall that, for whatever reason-perhaps rule (5)-the Case/ $\varphi$-deficiency of er does not block its appearance in the relevant construction in Dutch), we predict that, whenever we can determine independently that a verb assigns no external role, er should be allowed. This should hold, first of all, for ergative verbs; (51) shows that the class of ergative CP-selecting verbs is not limited to blijken.

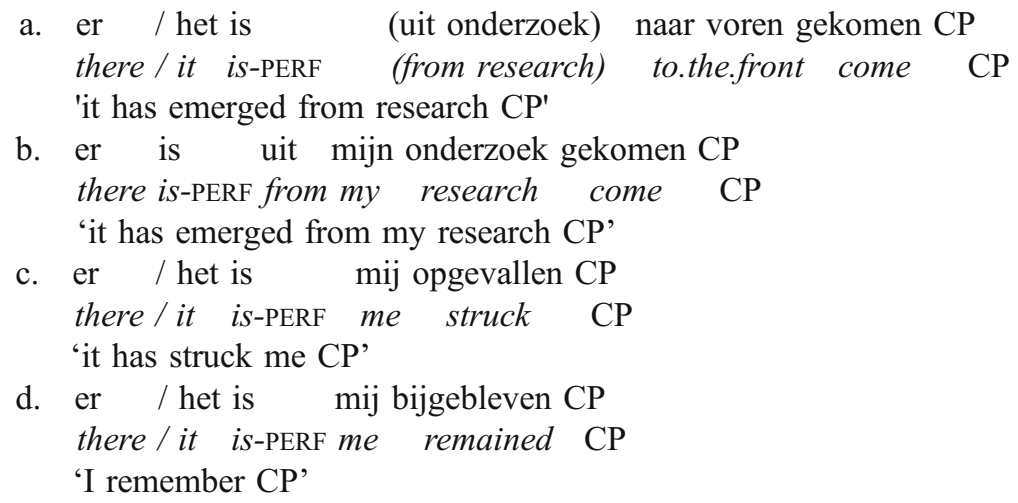

By auxiliary selection and adjective formation, these are ergative verbs; a subclass for which we typically expect ergative behavior are the experiencer verbs in (51c),

\footnotetext{
${ }^{22}$ There are two further distinctions between the blijken and schijnen verbs. First, the er-expletive with blijken may be dropped when some other element is available to satisfy (the Dutch counterpart of) the EPP (as is also the case in impersonal passives). But theta-marked het with schijnen, like het in ambience constructions, does not allow this variant (one anonymous reviewer feels het can sometimes be dropped with a schijnen-verb, but I (and my informants) disagree with this judgment, which contradicts Bennis 1986):

(i) a. mij is gebleken $\mathrm{CP}$

me is turned.out $\mathrm{CP}$

b. uit onderzoek blijkt $\mathrm{CP}$

from research turns.out $\mathrm{CP}$

(ii) * op grond van onderzoek lijkt CP on grounds of research seems $\mathrm{CP}$

The data in (i) and (ii) do not differentiate further between the theories discussed here (for Bennis, (ii) violates the c-selection properties of schijnen; a Williams-style analysis fails for the same reason it fails on (13) and (14)).

Of greater potential interest are the data in (iii), brought to my attention by an anonymous reviewer. Bennis (1986:104) (see also references cited there) argues that a CP that is linked to a CP-placeholder is opaque for extraction (presumably because it is an adjunct). On my assumptions, this predicts that blijken should allow extraction only when het is absent, whereas schijnen should allow extraction with het because het with schijnen is not a CP-placeholder. This is confirmed by the reviewer's judgments:
}

(iii) de man die het schijnt / *blijkt dat Jan gezien heeft the man who it seems / turns.out that Jan seen has

I tend to agree, but Bennis (p. 113) presents different judgments, so the issue requires further research. 
(51d). These verbs all allow the er-expletive, as predicted. A second class of verbs that allows us to test this prediction are passives:

(52) er / het werd betreurd CP

there / it is-PASs regretted $\mathrm{CP}$

As is well known, passive CP-selecting verbs in Dutch also allow the erexpletive; this is predicted by my account, as they assign no external role. I return to this construction in Section 7.

The second prediction is the following. When a CP-selecting verb allows er, it does not assign an external role. Hence, if we find the het-expletive with such a verb, it cannot be the quasi-argument. It also cannot be a pure expletive, since by hypothesis every het-expletive must bear a theta-role: there is no pure expletive het (assumption (48)). Hence, it must be a CP-placeholder. As a result, it must be in free variation with pseudo-clefting and relativization, and allow focusing. This prediction is correct as far as I can tell. It is illustrated in (53) and (54) for an ergative, ergative experiencer, and passive verb:

(53) a. wat uit onderzoek naar voren is gekomen is $\mathrm{CP}$ what from research to the.front is-PERF come is $\mathrm{CP}$ 'what has emerged from research is $\mathrm{CP}$ '

b. wat $\mathrm{mij}$ is opgevallen/bijgebleven is $\mathrm{CP}$ what me is-PERF struck / remained is $\mathrm{CP}$ 'what has struck me/ what I remember is $\mathrm{CP}^{\prime}$

c. wat (er) aangenomen wordt is $\mathrm{CP}$ what (there) assumed is-PASS is $\mathrm{CP}$

(54) a. alleen dit is uit onderzoek naar voren gekomen CP only this is-PERF from research to the. front come $\mathrm{CP}$ 'only this has emerged from research $\mathrm{CP}^{\prime}$

b. alleen dit is mij bijgebleven $\mathrm{CP}$ only this is-PERF me remained $\mathrm{CP}$ 'I remember only this $\mathrm{CP}^{\prime}$

c. alleen dit werd betreurd $\mathrm{CP}$ only this was-PASs regretted $\mathrm{CP}$

This prediction is in fact an instance of a more general constraint. We predict that no verb can pattern as in (55).

(55) proscribed pattern:
a. er V CP
b. het $\mathrm{V}$ CP
c. * wat $\mathrm{t}_{\mathrm{wat}} \mathrm{V}$ is $\mathrm{CP}$

Any two of the structures in (55) blocks the third. For instance, when het in (55b) occurs, but the pseudo-clefting wh-trace does not (55c) (as is the case with schijnenverbs), het must be a quasi-argument, hence $e r$ in (55a) should be blocked (as indeed it is). I am not aware of any verbs that show the pattern in (55).

It follows, furthermore, that we can check this prediction: there is no ergative (or passive) verb $\mathrm{V}$ which patterns as follows. 
(56) proscribed pattern:

a. het V CP

b. * wat $\mathrm{t}_{\mathrm{wat}} \mathrm{V}$ is $\mathrm{CP}$

Verbs like $\mathrm{V}$ in (56) do exist (schijnen / seem) but these are not ergative so they can assign an external role, making the het subject a quasi-argument. If $\mathrm{V}$ is ergative or passive, the quasi-argument is blocked; and since there is no pure expletive het, (56a) can occur only with CP-placeholder het; but this leaves no factor (such as c-selection against DP) that could block (56b). I know of no ergative/passive verb that patterns as in (56). ${ }^{23}$

A final prediction is illustrated in (57):
a. het $^{\mathrm{i}}$ werd $\mathrm{t}_{\text {het }}$ betreurd $\mathrm{CP}^{\mathrm{i}}$
it was-PASS regretted $\mathrm{CP}$
b. Ik redeneerde (*het) $\mathrm{CP}$
$I$ reasoned (*it) $\mathrm{CP}$
c. er /*het werd geredeneerd CP
there / *it was-PASS reasoned $\mathrm{CP}$

(57a) is my analysis of a passive CP-selecting verb with het-subject. Het must be a CP-placeholder: it cannot be a quasi-argument in the absence of an external role, and true het-expletives do not exist. Now consider a CP-selecting verb that disallows

\footnotetext{
$\overline{23}$ There is one apparent counterexample. The slightly archaic verb voorkomen fore.come 'appear' seems to pattern as follows (although intuitions are insecure):

(i) a. het komt mij voor $\mathrm{CP}$

it comes me fore $\mathrm{CP}$

'it appears to me CP'

b. * wat mij voorkomt is $\mathrm{CP}$

what me appears is $\mathrm{CP}$

c. het *heeft / ?? is mij voorgekomen CP

it has / is-PERF me appeared CP
}

To the degree that the verb allows a perfect tense, the be-auxiliary is preferred over the have-auxiliary, suggesting it is ergative. On the other hand, adjective formation is blocked. I want to suggest that the verb is not ergative, but inherits its choice of auxiliary from the ergative verb komen (from which it is derived). Evidence that such an inheritance process exists comes from the surprising fact that some verbs (binnenvallen, bijvallen, overeenkomen), which are also obtained by compounding with an ergative verb, take the be-auxiliary, but otherwise behave as transitives: they take a DP-internal argument, and allow passivization (note that passive in Dutch cannot promote an indirect object):

(ii) a. de Duitsers zijn ons land binnengevallen

the Germans are-PERF our country invaded

b. ons land werd binnengevallen door de Duitsers

our country was-PAss invaded by the Germans

Independent evidence that this analysis of voorkomen is correct comes from (iii). If voorkomen is indeed quasi-transitive, and its het subject the quasi-argument, the er-subject will be blocked (see the discussion of (55) in the text):

(iii) * er komt mij voor $\mathrm{CP}$

there comes me fore $\mathrm{CP}$ 
CP-placeholders; one such verb is redeneren 'reason' in (57b). Given that the CPplaceholder is blocked, and the quasi-argument cannot appear in a passive, the assumption that the true expletive does not exist predicts that this verb does not allow a passive with het. This prediction is confirmed by $(57 \mathrm{c}){ }^{24}$

\section{Some further exploration of the hypothesis}

The purpose of our reanalysis of the schijnen / blijken contrast was to provide evidence, independent of weather-verb and impersonal passive constructions, for a difference in theta-relatedness between the Dutch het and er-expletives, as stated in (48). This section briefly summarizes the evidence so far, and adds some additional considerations.

Firstly, if our analysis is correct, we have evidence that er does not need a thetarole: it can appear as the subject of ergative (and passive) (CP-selecting) verbs, where an external theta-role is not available (see (14b), (51), (52)).

Secondly, we have evidence that er cannot bear a theta-role: $e r$ is excluded as the subject of schijnen-verbs, because these assign an external quasi-role (see (13b)), on our analysis.

Thirdly, we have evidence that het can bear a theta-role, by the same reasoning: het is allowed as the subject of schijnen verbs (see (13a)).

Lastly, we have evidence that het must bear a theta-role. First of all, this explains why every het that occurs as the subject of a verb without external theta-role is a CPplaceholder (see (53) through (56)): there is no real expletive het. Secondly, it explains how passives of verbs like redeneren that disallow CP-placeholders, can disallow het subjects (see (57)).

It follows, that Hazout's (2004) account of expletive selection discussed in the introduction, which assumes that English it and there do not differ in their thetaproperties, does not extend to Dutch.

Section 6.1 provides some additional empirical evidence in support of the postulated theta-properties of er and het; Section 6.2 addresses some issues of technical implementation.

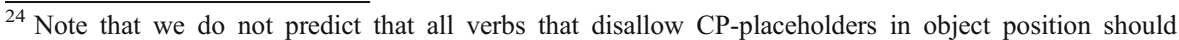
behave like redeneren. It is well known that verbs idiosyncratically allow or disallow CP-placeholders depending on factivity and other factors; some disallow them in object position but not, with passivization, in subject position (aannemen 'assume' and beweren 'claim' are examples). There is also some speaker variation; e.g., for Reuland $(1983,1985)$ and others, but not Bennis (1986), beweren 'claim' is in the same category as redeneren. The exact conditions on the appearance of the CP-placeholder fall outside the scope of this paper. What we do predict is that the pattern in (57) with redeneren can exist; if the grammar allowed a non-theta-marked het expletive, het in $(57 \mathrm{c})$ could not be blocked. The following alternative explanation for (57) might be suggested: verbs like redeneren are (associated with a $v$ that is) inherently incapable of checking Case. Then, on a theory of Case absorption in passives as sketched in (12), (57c) might be blocked because only Nominative is available for both the passive morphology and het. But this would not extend to beweren 'claim', which for many speakers (like Reuland) patterns like redeneren, but can take a DP internal argument.
} 


\subsection{Further evidence}

Some additional evidence for the postulated properties of er may come from (58):
a. het ziet $\left[\mathrm{PP} \quad \mathrm{er}_{[+\mathrm{R}]}^{\mathrm{i}}\right.$ naar] uit $\mathrm{CP}^{\mathrm{i}}$
it looks $\left[i t_{[+\mathrm{R}]}\right.$ to $]$ out $\mathrm{CP}$
'it looks like it CP'
b. * er ziet $\left[\mathrm{PP} \mathrm{er}^{\mathrm{i}}{ }_{[+\mathrm{R}]}\right.$ naar $]$ uit $\mathrm{CP}^{\mathrm{i}}$
there looks $\left[i t_{[+\mathrm{R}]}\right.$ to $]$ out $\mathrm{CP}$
c. $\operatorname{waar}_{[+\mathrm{R}]}$ het $\left[\mathrm{PP} \mathrm{t}_{\mathrm{waar}}\right.$ naar] uit ziet is $\mathrm{CP}$ what ${ }_{[+\mathrm{R}]}$ it $[\mathrm{t}$ to $]$ out looks is $\mathrm{CP}$
'what it looks like is CP'

(58a) contains two expletives: one in subject position, and one as the complement of the postposition naar (confusingly, the second expletive takes the shape of er: this is in fact not the er-expletive under discussion here, but the [+R] variant of het that appears as the complement of adpositions; see Van Riemsdijk (1978)). Clearly, the two expletives cannot both be CP-placeholders; the pseudo-clefting example (58c) shows, unsurprisingly, that the complement of the postposition is the CPplaceholder. Since the subject expletive is not a CP-placeholder, and our theory excludes a pure expletive het, we predict that it must be a (quasi-)argument (and indeed, the verb does not behave as ergative for auxiliary selection). As a result, we correctly predict that er is blocked: see (58b). This provides further evidence that $e r$ cannot bear a theta-role (but het can), but the evidence is not (yet) decisive: since the subject expletive in these cases is not CP-linked, the construction has the same properties as the weather-verb construction, hence might allow the same Case/ Agreement analysis as (8) above: perhaps het is needed here to check $\varphi$ on T.

A related argument can be based on Danish:
a. at $\operatorname{det} / * \operatorname{der} \operatorname{lod}[\mathrm{PP}$ til CP ]
that it /*there seemed to $\mathrm{CP}$
b. at *det / der blev regnet [PP med CP ] that $*$ it / there was counted with $\mathrm{CP}$

Danish; Vikner (1995:266/247)

The Danish counterpart of the seem-construction in (59a), with the CP in a PP complement, disallows the there-expletive just like Dutch (58b), whereas the impersonal passive construction (59b), in the absence of an external theta-role, blocks the quasi-argument it-expletive (CP-placeholder det is not allowed in (59b) because Danish does not have pseudo-passives). But again, one could assume instead that det in (59a) is needed to check $\varphi$ on T, while PRT in (59b) absorbs NOM, blocking det. I return to (58) and (59) in Section 7 below.

There is also some additional evidence for the postulated properties of het. Consider the speaker-oriented Slifting parenthetical (Ross 1973; Reinhart 1983) in (60a):

(60) a. de koningin, (zo) beweerde Jan, houdt van spruitjes.

'The queen, so claimed Jan, likes Brussels sprouts.'

b. ?? de koningin, (zo) beweerde Jan iets opmerkelijks, houdt van spruitjes.

'The queen, so claimed Jan something remarkable, likes Brussels sprouts.' 
In this construction, the propositional internal argument of certain CP-selecting verbs is suppressed, and the resulting phrase parenthetically attached to a main clause that is interpreted as bearing the verb's internal theta-role. The parenthetical clause is optionally accompanied by a pronominal adverb such as zo 'thus, so'. ${ }^{25}$ Unsurprisingly, since the direct object function is already performed by the main clause (perhaps mediated through a fronted operator, see Corver and Thiersch (2001) and references cited there), the verb in the parenthetical cannot take a direct object: see (60b). Accordingly, we expect that a CP-placeholder will also be blocked inside the parenthetical. Thus, constructions that ordinarily allow an optional CP-placeholder disallow it in the parenthetical:

(61) a. Jan bracht (het) onder onze aandacht dat de koningin van spruitjes houdt 'Jan brought (it) to our attention that the queen likes Brussels sprouts.'

b. de koningin, (zo) bracht Jan (*het) onder onze aandacht, houdt van spruitjes

'The queen, (so) brought Jan (it) to our attention, likes Brussels sprouts.'

whereas verbs that require a CP-placeholder cannot appear in this construction:

(62) a. Jan haat ??(het) / vindt ??(het) jammer CP

'Jan hates (it) / finds (it) deplorable CP'

b. * de koningin, zo haat Jan (het) / vindt Jan (het) jammer, houdt van spruitjes.

'The queen, so hates Jan (it) / finds Jan (it) deplorable, likes Brussels sprouts.'

The data in (62) are as expected: since het is required with these verbs, omitting it in (62b) is disallowed, but retaining it is as well, since the construction requires absorption of the internal argument (we cannot, of course, rule out that these verbs are also blocked for some other, presumably semantic reason). We find the same pattern with the obligatory CP-placeholders that appear in argument PPs:

(63) a. * De koningin, zo rekent Jan (er) op, zal de troonrede uitspreken. 'The queen, thus counts Jan (it ${ }_{[+\mathrm{R}]}$ ) on, will deliver the Queen's speech.'

b. De koningin, zo verwacht Jan, zal de troonrede uitspreken. 'The queen, thus expects Jan, will deliver the Queen's speech.'

(63a) is blocked both with and without the obligatory CP-placeholder complement of $o p$, even though a DP-selecting verb with the same meaning is allowed in (63b).

Given this background, consider the passives in (64):

(64) a. het werd aangenomen/aangetoond dat de koningin van spruitjes hield.

'It was-PASS assumed/demonstrated that the queen liked Brussels sprouts.'

b. de koningin, zo werd (*het) aangenomen/aangetoond, houdt van spruitjes. 'The queen, thus was-PASs (it) assumed/demonstrated, likes Brussels sprouts.'

\footnotetext{
$\overline{{ }^{25}}$ To avoid confusion: Dutch zo is not the result of So-pronominalization.
} 
Verbs like aannemen 'assume' and (for some speakers) aantonen 'demonstrate' in (64a) allow a CP-linked het-expletive (a CP-placeholder, on my analysis) in the passive. These passives are also allowed in the parenthetical construction (64b), but only without the het subject. How can this be explained? We can understand why the CP-placeholder is blocked: the construction requires suppression of the propositional argument. We can also understand why the quasi-argument is blocked: passives assign no external role. But what could block merger of a pure expletive het? On our analysis, what blocks the pure expletive het is that there is no pure expletive het.

This version of the argument is not yet decisive, however, in view of the, now familiar, alternative analysis in terms of Case/Agreement. Since the passive verbs in (64b) have no internal argument, these constructions are instances of impersonal passives. Hence, if one rejects the analysis of impersonal passives on the basis of default $\varphi$-checking (see (5)), and adopts instead the analysis in (12), then one can block het on the grounds that T cannot satisfy the checking requirements of both het and the passive participle head PRT.

A version of the argument that does not depend on Case/Agreement assumptions again utilizes the schijnen / blijken contrast. On our analysis, a het-subject should not be allowed in case we are dealing with an ergative or passive verb, but should be allowed with one that assigns a (quasi-)theta-role that het can bear. This holds true for ambience verbs, for instance:

(65) Ga maar slapen, ga maar slapen, zo roffelde het op mijn zolderraam.

'Go to sleep, go to sleep, so it pattered on my attic window.'

More significantly, we find the expected difference between schijnen-verbs and blijken-verbs:

(66) a. De koningin, zo lijkt*(het), houdt van spruitjes.

'The queen, so it seems, likes Brussels sprouts.'

b. De koningin, zo blijkt (*het) uit onderzoek, houdt van spruitjes.

'The queen, so it turns out from research, likes Brussels sprouts.'

c. De koningin, zo is (*het) naar voren gekomen, houdt van spruitjes.

'The queen, so it has emerged, likes Brussels sprouts.'

I have argued that the expletive with schijnen-verbs is not a CP-placeholder, but a quasi-argument: it therefore may, and must, be present in (66a). ${ }^{26}$ The crucial examples are (66b) and (66c). Het is disallowed with ergative blijken in (66b) and naar voren komen in (66c), as CP-placeholder het is blocked by the construction, and quasi-argument het would receive no theta-role. In these examples, Case/ Agreement considerations could not block the pure het-expletive, if it existed;

\footnotetext{
${ }^{26}$ A deviation from the pattern (66a) is De koningin houdt van spruitjes, lijkt me 'the queen likes Brussels sprouts, seems to.me', with a fixed expression which I suspect is a Slifting variant of the exceptional (33a).
} 
hence, the fact that het is disallowed confirms our assumption that het must bear a theta-role. $^{27}$

Clearly, these remarks must remain tentative, pending a full treatment of the Slifting construction; but the initial evidence suggests that it confirms our approach to het-expletives.

\subsection{Merger of expletives}

This section addresses a technical question raised by the analysis of expletive selection proposed here. Consider again the schijnen-verb paradigm in (50) (repeated).

(50) a. het schijnt CP

b. * er schijnt CP

c. * het schijnt DP

d. * DP schijnt $t_{D P}$

e. * CP schijnt $\mathrm{t}_{\mathrm{CP}}$

I argued in Section 4.3 that (50b) is blocked because er cannot bear the external quasi-theta role assigned by schijnen. I also argued in Section 2 that, if Dutch allows default $\varphi$-feature checking by rule (5), the same reasoning is required to rule out er with weather verbs:

(8) a. het regende

b. * er regende

However, we can only exclude (50b) and (8b) in this manner if er must be merged in the position where the quasi-theta role is assigned. And it is commonly assumed that subject there-expletives (and putative pure it-expletives) are exempt from the VP-internal Subject Hypothesis: they are not first merged in VP (or vP), but in Spec, IP, where they satisfy the EPP (see, e.g., Chomsky 1981). This section briefly considers some ways in which this problem might be resolved, although a full discussion of the conditions on expletive insertion is beyond the scope of this paper. It is important to note, though, that the problem is not particular to my analysis of schijnen-verb: given this analysis, it becomes just an instance of the more general issue of how to block *there reads a book.

\footnotetext{
${ }^{27}$ Related facts in English were noted by Ross (1973). He "confess[es] bafflement" (footnote 4) at the contrast exemplified by (i):

(i) a. He has only one left foot, it seems to me.

b. * He has only one left foot, I explained it to Jo.
}

We are unbaffled by (i), which conforms exactly to our predictions. However, further examples indicate an apparent breakdown of the parallelism between Dutch het and English it. Next to the expected quasiargument $i t$-expletive in (ia), we also find an it-expletive in (ii) ((iia) from Ross (1973:fn. 4)):

(ii) a. It rained, it is true.

b. ? CP, or so it is claimed/believed.

On first inspection, the facts in (ii) seem to indicate that English it can appear without a theta-role; I must leave these examples for further research. 
One solution would be to postulate that the er-expletive is indeed merged in Spec,IP, and that the ill-formedness of (50b) and (8b) does not result from er being assigned a theta-role, but from the external quasi-theta-role remaining unassigned. This will block (50d) and (50e) as well. ${ }^{28}$ However, this solution presupposes that theta-roles must be discharged. As a C-I interface requirement, this might be plausible in some cases, but not in the cases at hand: it would be hard to argue that a quasi-role remaining unassigned would lead to semantic oddity. And while the existence of quasi-theta roles without semantic import may in itself constitute an argument against removing theta theory from narrow syntax, obligatory theta discharge also does not appear plausible as a grammatical requirement (see Chomsky 1981, 1995, and esp. 1986:143 for some discussion). For this reason, although an assumption of obligatory theta-discharge would deal with the facts immediately, I want to explore an alternative that does not rely on this assumption.

The alternative solution I want to pursue is that expletives are never merged in Spec,IP, but always in $\operatorname{spec}, v \mathrm{P}$. Rather than introducing a complication, this assumption removes an anomaly. In order to allow expletives to merge directly in their feature-checking position in Spec,IP, Chomsky (1995) needed to stipulate that expletives, exceptionally, engage in $\varphi /$ case checking upon first merge (which is disallowed, e.g., for subjects merging in spec, $v$, or they would check Accusative). Likewise, the exemption of expletives from the VP-internal Subject Hypothesis forced Chomsky (2000) to assume that the expletive can act as Probe, finding Goal $\mathrm{T}$ (the reverse, $\mathrm{T}$ probing the expletive, is not possible if the expletive is first merged in Spec,TP). This requires the otherwise unmotivated assumption that expletive pronominals are bare heads, whereas other pronominals, which must not be allowed to probe, must contain some further internal structure. If, on the other hand, expletives are merged in spec, $\nu \mathrm{P}$ and move to $\mathrm{T}$, no special assumptions are required. There are also empirical advantages. In the framework of Chomsky (2000), if the expletive can probe, this predicts incorrectly that a there-expletive always becomes inert after first merge: in an example such as there seems $t_{\text {there }}$ to be someone in the room, the expletive as a probe will Match and Agree with the embedded $\mathrm{T}$ (or even with someone) at first merge; this is enough to delete the single uninterpretable feature [person] on the expletive, rendering it ineligible for subsequent raising to subject (the problem is discussed at length in Ruys 2003; see also Bošković 2002:fn.50 for some discussion). Various solutions can be considered; as was pointed out by Ten Have (2004), the problem disappears if the expletive is merged in $\mathrm{spec}, v \mathrm{P}$, and does not probe but is probed by $\mathrm{T}$, like any normal argument: then it becomes inert only upon reaching the (non-defective) matrix $\mathrm{T}$.

\footnotetext{
${ }^{28}$ But for these cases, alternative solutions are available: (50d) can be blocked by c-selection, and so can (50e) on a Koster (1978) style approach to subject CPs; alternatively, it may be supposed that the movement operations in (50d) and (50e) can be blocked by phase theory (see Chomsky 2008 and references cited): if schijnen assigns both an internal and external role, the dominating strong $v \mathrm{P}$ phase should block Agree from T (unless a phase is only closed off at the next phase boundary, as in Chomsky 2001). In any case, the issue goes beyond expletives and does not need to be addressed here: if schijnen is transitive, (50d) and (50e) are blocked by whatever blocks *this book reads.
} 
Assume, therefore, that expletive subjects-i.e., er and quasi-argument het-are merged in spec, $v \mathrm{P}$ (CP-placeholder het of course is merged wherever its non-quasi role is assigned). ${ }^{29}$ We can show that expletive selection can then be determined by ergativity or unergativity of the verb, as argued above. We have the following situations to consider. $\mathrm{V}$ can be transitive or unergative intransitive, with $v$ assigning an external role (following Chomsky $2001 \mathrm{I}$ will write this $v$ as $v^{*}$; perhaps the light verbs associated with transitives and unergatives have different Case properties, a refinement we can ignore here), or $\mathrm{V}$ can be ergative intransitive (with passive as a special case), with $v$ not assigning a theta-role (notation: $v^{-}$).

a.
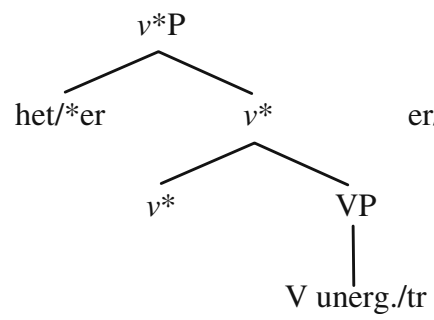

b.

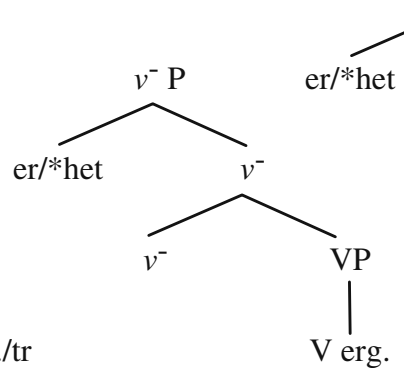

c. $\quad v^{*} \mathrm{P}$

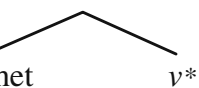

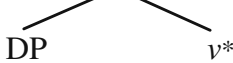

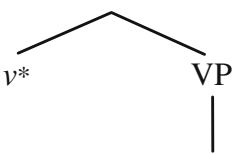

V unerg./tr

Het must be merged in a theta-position. The only option therefore is the inner (theta-marked) spec, $v^{*}$ occurring with transitives and unergative intransitives, as indicated in (67a); excluded is the spec, $v^{-}$of ergative intransitives, as in (67b), and an outer (non-theta-marked) spec, $v^{*}$, as in (67c).

Er/there may not be merged in a theta-position, so the theta-marked inner spec, $v^{*}$ of (67a) is excluded, but merger is allowed in the spec, $v^{-}$of ergative intransitives, as in (67b). For er/there, there is an additional option: merger in a second, outer (nontheta-marked) spec, $v^{*}$, if available, as indicated in (67c). Whether an outer spec, $v^{*}$ is available for this purpose depends on whether or not the language has TECs. Needless to say, this is not the place to develop a theory of TECs; but on our approach, the difference between TEC languages like Dutch, which allow thereinsertion with transitives and unergatives, and non-TEC languages like English, can be described as the availability or non-availability of an outer spec, $v$ created by first merge; see Van Zoelen (2005) for a theory of the cross-linguistic variation in TEC constructions that is based on this description.

Consequently, we find het with CP-selecting schijnen/seem, including the PPselecting seem-verb uitzien in (58), as these are unergatives (whether the assignment of a quasi-role requires a special version of $v^{*}$ is a question we will leave open here): see (67a). We find er / there with ergative blijken and its kin (51) and with CPselecting passives (52): see (67b). Beyond CP-selecting verbs, we find het with

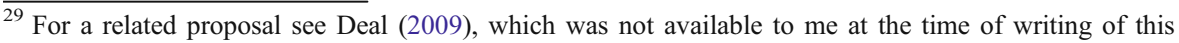
article.
} 
(unergative or transitive ${ }^{30}$ ) ambience verbs (67a), but er/there with passives (both normal and impersonal) and ergatives, including presentational verbs (appear) (67b). In addition, in TEC Dutch we find $e r$, in combination with an agentive subject, with unergatives and transitives (67c).

I have argued that expletives merge in spec, $v \mathrm{P}$ : I have demonstrated how this accounts for expletive selection with all verb types discussed here. But one technical issue remains to be resolved: what guarantees that expletives merge only in spec, $v \mathrm{P}$ ? In most cases, merging an expletive directly in Spec, TP will cause the derivation to crash, since we assume it cannot check its features by probing $\mathrm{T}$, and $\mathrm{T}$ cannot probe its specifier. But suppose we have a structure (67a) (which should disallow er / there) dominated by a non-tensed TP; and suppose there is first merged in the specifier of this $\mathrm{T}$, and then attracted by the $\mathrm{T}$ of a dominating tensed clause: this will satisfy the properties of the expletive, while circumventing merger and proscribed theta-marking in spec, $v^{*}$. I want to suggest a tentative solution based on a discussion in Chomsky (2008). Suppose that, theta-theory apart, satisfaction of the featurechecking and EPP-requirements of a head can only be satisfied by an element Agreeing with that head. If so, first merge in Spec, XP will never check features of X or satisfy X's EPP-requirement. In the example under discussion, if an expletive merges in Spec,TP then the EPP requirement of that $\mathrm{T}$ is not satisfied. I must leave further discussion of the details of this solution for another occasion, except to point out one immediate consequence: it works only on the assumption that every $\mathrm{T}$, including non-tensed T, must satisfy the EPP, contra, e.g., Bošković (2002). But note that this is already entailed by our account. If expletive selection is to be partly determined by theta-theory, we must prevent expletives from being merged in the matrix clause of a raising construction, whether it be in Spec, TP or spec, $\nu$ P: selection is always determined by the theta-properties (ergativity or non-ergativity) of the embedded verb, not of the raising verb (see, e.g., the data in (23) above). ${ }^{31}$

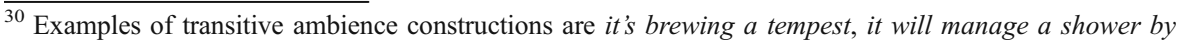
this afternoon, it's oozing oil. A CP-selecting transitive verb of this type occurs in it says in the Bible CP (examples from Bolinger 1973).

${ }^{31}$ There is one further important technical question, which I cannot resolve here: what is the relation between the $\mathrm{CP}$-selecting verbs discussed in the text, and their raising variants? Like seem, both schijnen and blijken have raising counterparts. Raising blijken is unproblematic: it has the same ergative properties as CP-selecting blijken, assigning neither Accusative nor an external theta-role, the only difference being that its internal theta-role is assigned to an IP. Raising schijnen / seem is less straightforward: what happens to the supposed external quasi-theta-role? The question is not so much why it may remain unassigned, so long as we do not opt for a theta-theory that requires all roles to be discharged. But we are faced with the problem how the raising subject can cross the $v^{*} \mathrm{P}$ projected by transitive seem, in possible violation of phase theory (cf. footnote 28 above). And a further question is why the external theta-role must remain unassigned when seem takes a non-tensed, IP complement. Some derivations will be blocked by Case theory: if het / it is merged as matrix subject, Nominative case is not available for the embedded subject. But it remains to be explained why an ECM construction, as in (i), is blocked:
}

(i) * it seems [IP him to have won the race]

Since seem in (i) assigns an external theta-role, Burzio's generalization entails that it can assign Accusative Case to him. We can solve both problems by assuming that the variant of seem that can cselect IP is ergative (projects $v^{-}$), and does not assign an external role. Further research must determine whether a principled basis can be found for this assumption. 


\section{Back to impersonals}

This section returns to the Case/Agreement properties of the constructions under discussion. In Section 2 above, I argued that a rule such as (5) would be one way to explain why Dutch and Danish allow impersonal passives, while English does not, and that, given such a rule, expletive selection in impersonal passives and ambience constructions provides evidence for the different theta-properties of er and het proposed here.

\section{(5) Default $\varphi$-valuation}

Dutch, Danish $(, \ldots)$ have a rule of default valuation $[3, \mathrm{sg}]$ and deletion of $\varphi$ on T; English does not.

We now have independent evidence for this rule from the impersonal constructions involving blijken-type verbs discussed in the foregoing sections, which we might call 'impersonal ergatives.' Consider again some of the examples:
a. er blijkt (uit onderzoek) $\mathrm{CP}$
there turns.out (from research) $\mathrm{CP}$
b. er is (uit onderzoek) naar voren gekomen CP
there is-PERF (from research) to the.front come $\mathrm{CP}$
'it has emerged from research CP'

The existence of these constructions is what we expect, given rule (5): the uninterpretable $\varphi$-features on $\mathrm{T}$ can be deleted by the default rule. This analysis predicts, furthermore, that impersonal ergatives appear in exactly those languages that allow impersonal passives. For the small sample taken here, this is correct: Danish also allows the impersonal ergative construction, as pointed out by Vikner (1995), ${ }^{32}$ but English does not, as pointed out above:

$$
\begin{aligned}
& \text { ? at der siges } \mathrm{CP} \\
& \text { that there said.is } \mathrm{CP}
\end{aligned}
$$

Danish; Vikner (1995:257:(97))

\section{b. ${ }^{*}$ there TURNS-OUT CP}

The alternative analysis of feature checking in impersonal passives considered in Section 2 does not extend to the impersonal ergative construction. We considered the option that it is the passive morphology that checks Nominative and satisfies $\mathrm{T}$ in impersonal passives, as originally proposed by Roberts (1985)-see the discussion surrounding (12). But Dutch impersonal ergatives do not show passive morphology. ${ }^{33}$

\footnotetext{
32 The verb in (69) is morphologically a (synthetic) passive (Vikner, loc. cit.). As with Dutch blijken, the it-expletive (CP-placeholder) is allowed as well:

(i) at det siges $\mathrm{CP}$

that it said.is $C P$

${ }^{33}$ Other options mentioned in section 2 also fail: there is no room in impersonal ergatives for a hidden 'cognate object' (contra Mohr 2002; see footnote 7); the optional experiencer bears Dative and does not trigger agreement, and it can be definite, which should be excluded if it formed a Case CHAIN with the erexpletive. Yet another option is that the er-expletive checks Case (Lasnik 1999; Hazout 2004) here (but not elsewhere, and not in English). I do not believe this to be correct, but if it were, this would of course render my argument for a theta-distinction between er and het all the more straightforward, as it would remove Case as a factor that could account for expletive selection (since het is also assumed to check Case). A direct argument against er satisfying the $\varphi$-checking and Case-assignment needs of $\mathrm{T}$ in impersonal ergatives is, of course, the optionality of er (see footnote 22).
} 
I propose, therefore, that we reject the alternative analysis of Case/Agreement in impersonals sketched in (12), and adopt (5) as a (presumably lexical) rule. It follows, as explained in Section 2, that several pieces of independent evidence for the postulated theta-properties of er and het come into force. Selection of er and blocking of het in impersonal passives and in the passive Slifting cases (64) shows that er need not bear a theta-role, but het must. Selection of het in ambience constructions, in the double expletive construction (58), and of det in the Danish seem-construction (59a) shows that het can bear a theta-role but er cannot. Assuming the correctness of (5) or some similar account, these facts all provide additional support for our proposal that er is not theta-marked, but het is. ${ }^{34}$

Naturally, my argument for (5) goes through only in the absence of an alternative and better analysis of Case/Agreement in impersonal passives that might be extended to impersonal ergatives. I am aware of one such account: that of Vikner (1995). Vikner proposes that in impersonal passives the expletive forms a CHAIN with the participial ending (as in Roberts 1985), but in impersonal ergatives the expletive forms a case-CHAIN with the CP complement of the verb, as shown below:

(11) b. er
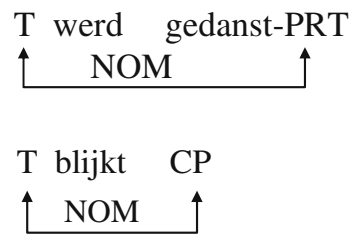

impersonal passive

impersonal ergative

If we incorporate this in the minimalist implementation of Roberts (1985) sketched in (12), this would mean that whereas in the impersonal passive (11b), the participial ending Agrees with $\mathrm{T}$, in the impersonal ergative (70) it is the CP complement that values and deletes the uninterpretable $\varphi$-features on $\mathrm{T}$, and absorbs nominative Case.

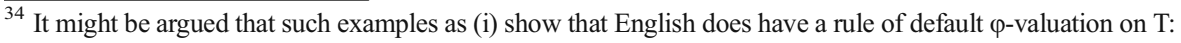

(i) there's a few problems with that
}

However, while I do not have a strong opinion about the proper analysis of these cases, it does not involve the type of default $\varphi$-valuation on T I am attributing to Dutch. First of all, Dutch does not allow the process in (i): in the Dutch translation, agreement is obligatory. Secondly, the rule of default $\varphi$-valuation I am proposing entails absorption of Nominative in the framework I have adopted; by such a rule, (i) should crash. Hence, whatever rule is operative in (i) (let's call it rule R), it is not my rule (5). As a result, I can, without contradiction, maintain that English does not have rule (5), and therefore disallows the impersonal ergative construction. My theory need not, furthermore, predict that English should allow impersonal ergatives because it has rule R, for two reasons: 1) Rule R has a very limited scope, and does not apply to seem-verbs but only to be, and sometimes only to certain instances of be (e.g., only to copula be in wh-questions: Schütze 1999) (although Schütze allows there appears to be some men in the garden); and 2) since Rule R does not absorb case for the associate (wherever it originates), even if it turns out that rule $\mathrm{R}$ can delete the uninterpretable features on $\mathrm{T}$, it might be that impersonal ergatives are blocked because this case remains unassigned. See Schütze (1999) and references cited there for further discussion. 
Setting aside the question whether $\varphi$ - and nominative checking by VP-internal CPs is a defensible proposition, I feel that this alternative approach has one major drawback: it does not allow a uniform description of the cross-linguistic variation we have observed. Vikner explains the impossibility of impersonal passives such as (11b) in English by assuming that the English passive participial ending cannot form a CHAIN with there (on a minimalist implementation: has incomplete $\varphi$-features). However, this account does not predict that impersonal ergatives are equally impossible. In order to extend the account to impersonal ergatives, one must assume that the English VP-internal CP also cannot form a Case-CHAIN with the expletive (cannot check $\varphi /$ nominative). Vikner formulates such a restriction in his discussion of passives with VP-internal CP arguments, as in (71):

(71) a. er wordt beweerd CP

there is-PASS claimed $\mathrm{CP}$

b. * there is claimed $\mathrm{CP}$

c. at der blev sagt CP

that there was-PASS said $\mathrm{CP}$

[Danish; Vikner (1995:243)]

On our account, these data fit the general pattern. The er-expletive is selected because there is no external argument; $\varphi$ on T in Dutch (71a) and Danish (71c) is checked by rule (5), absence of default checking blocks English (71b). Vikner proposes that in Dutch / Danish, the internal CP argument is the foot of a CaseCHAIN with nominative, just as in impersonal ergative (70), but that this option is blocked in English, because of an additional constraint which prevents CHAINformation between there and the CP. This means that there are two constraints in English: expletive-participial CHAINs are blocked for impersonal passives (7a); and expletive-CP CHAINs are blocked for CP-passives (71b). Vikner argues that there is independent evidence for the second constraint: expletive-internal argument CHAINs are always marked in English passives, not just with CPs:

?? there was killed a man

However, this independent evidence does not extend to impersonal ergatives. Consider the full English paradigm:

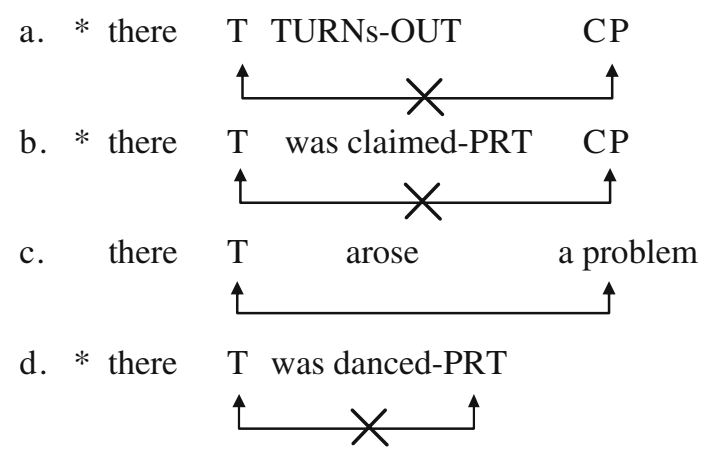

In order to block the English impersonal ergative (73a), Vikner needs to extend the ban on expletive-CPs CHAINs to ergative constructions. But this prohibition is not 
Table 2 Two types of languages

\begin{tabular}{ll} 
Dutch / Danish & English \\
\hline Impersonal passive & No impersonal passive \\
Impersonal ergative (blijken; siges) & No impersonal ergative (emerge)
\end{tabular}

reducible to a general ban on CHAINs in this construction, as might be argued for the passive case (73b), since we know that (a subset of) English ergatives do allow a CHAIN between there and a (nominal) internal argument: see (73c). Hence, we are left with two separate distinctions between Dutch/Danish and English: expletive-CP CHAINs in impersonal ergatives are allowed in Dutch/Danish but not English; and expletive-participial CHAINs in impersonal passives are allowed in Dutch/Danish but not English. In a minimalist implementation: CP can check Nominative and $\varphi$ on $\mathrm{T}$ in Dutch/Danish but not English; and the participial ending can check Nominative and $\varphi$ on $\mathrm{T}$ in Dutch/Danish but not English.

One might suspect that the absence of a blijken type verb in English could be an accidental lexical gap. However, English has a verb that would seem to fit the requirements for this construction exactly:

(74) a. some new facts emerged

b. the recently emerged facts

c. there emerged some new facts

d. it emerged $\mathrm{CP}$

e. what emerged was $\mathrm{CP}$

f. * there emerged $\mathrm{CP}$

Emerge in (74a) is ergative (thus, it allows adjective formation: (74b)), and can appear in the presentational construction (74c) with the argument VP-internal and a there-expletive (it is one of Milsark's (1974) "inside verbals"). It allows a propositional argument in (74d) (with the it-expletive a CP-placeholder, allowing pseudo-clefting (74e)), but it does not allow the impersonal ergative construction (74f).

I tentatively conclude that the analysis in terms of rule (5) is to be preferred, as it provides one uniform account of all three relevant distinctions between Dutch/Danish and English: English lacks default $\varphi$-valuation, hence disallows

Table 3 Two types of verbs

\begin{tabular}{ll}
\hline Blijken & Schijnen / seem \\
\hline er and het & only het / it \\
$\begin{array}{l}\text { pseudo-clefting, relativization, right-dislocation, } \\
\text { focusing }\end{array}$ & no pseudo-clefting, relativization, right-dislocation, \\
focusing \\
eP in subject-position & no CP in subject-position \\
ergative & unergative \\
loses het in Slifting & retains het in Slifting \\
\hline
\end{tabular}


impersonal passives, impersonal ergatives, and there insertion with CP-passives as in (71).

\section{Conclusions and further research}

In this paper I have argued for the following assumptions.

\section{(5) Default $\varphi$-valuation}

Dutch, Danish $(, \ldots)$ have a rule of default valuation $[3, \mathrm{sg}]$ and deletion of $\varphi$ on T; English does not.

(48) The het-expletive must bear a theta-role, the er-expletive cannot.

These assumptions allow us to describe the pattern of cross-linguistic variation shown in Table 2, as well as the distinctions among CP-selecting intransitive verbs shown in Table 3.

The evidence for (48) that is based on the blijken vs. schijnen/seem contrast does not depend on (5). If (5) is accepted, additional evidence for (48) comes from impersonal passives and ambience constructions.

Various questions remain to be resolved. In particular, further research is needed to establish whether the theory of expletive merger put forward in Section 6.2 can be maintained. Also, further research must determine whether the distinction I have drawn between English/Dutch/Danish there/er/der and it/het/det extends to other Germanic languages such as German, in which the difference between two expletive types is less easily discerned, ${ }^{35}$ and to languages outside this family (and indeed, to English, given the facts in footnote 27).

On a more concrete note, I must leave for future research the following puzzling gap in the paradigm of Dutch impersonal ergative constructions:
a. er ontstaat DP
there arises DP
b. er blijkt CP
there turns.out $\mathrm{CP}$
c. * er V PP

Acknowledgements Thanks are due to Jutta Hartmann, Johan Kerstens, Ora Matushansky, Jacomine Nortier, Henk van Riemsdijk, audiences at Coloquio de Gramática Generativa (CGG) 15 and the CLS Colloquium at Radboud University, and anonymous JCGL reviewers. All remaining errors are of course my own.

Open Access This article is distributed under the terms of the Creative Commons Attribution Noncommercial License which permits any noncommercial use, distribution, and reproduction in any medium, provided the original author(s) and source are credited.

\footnotetext{
35 The difference, if it exists, shows up only in whether the expletive is dropped in certain contexts. In addition, the class of usages under which the expletive is dropped is not constant across languages.
} 


\section{References}

Bennis, Hans. 1986. Gaps and dummies. Linguistic Models 9. Berlin: Foris.

Bolinger, Dwight. 1973. Ambient it is meaningful too. Journal of Linguistics 9: 261-270.

Bošković, Željko. 2002. A-movement and the EPP. Syntax 5: 167-218.

Bresnan, Joan. 1972. Theory of complementation in English syntax. Doctoral dissertation, MIT.

Cardinaletti, Anna, and Michal Starke. 1996. Deficient pronouns: A view from Germanic. A study in the unified description of Germanic and Romance. In Studies in comparative Germanic syntax, vol. 2, ed. Höskuldur Thräinsson, Samuel David Epstein, and Steve Peter, 21-65. Dordrecht: Kluwer.

Chomsky, Noam. 1981. Lectures on government and binding. Dordrecht: Foris.

Chomsky, Noam. 1986. Knowledge of language. New York: Praeger.

Chomsky, Noam. 1991. Some notes on economy of derivation and representation. In Principles and parameters in comparative grammar, ed. R. Freidin, 417-454. Cambridge, MA: MIT Press.

Chomsky, Noam. 1995. The minimalist program. Cambridge, MA: MIT Press.

Chomsky, Noam. 2000. Minimalist inquiries: The framework. In Step by step: essays on minimalist syntax in honor of Howard Lasnik, ed. Roger Martin, David Michaels, and Juan Uriagereka. Cambridge, MA: MIT Press.

Chomsky, Noam. 2001. Derivation by phase. In Ken Hale: a life in language, ed. M. Kenstowicz, 1-52. Cambridge, MA: MIT Press.

Chomsky, Noam. 2008. On phases. In Foundational issues in linguistic theory. Essays in honor of JeanRoger Vergnaud, ed. Robert Freidin, Carlos P. Otero, and Maria Luisa Zubizarreta, 133-166. Cambridge, MA: MIT Press.

Corver, Norbert, and Craig Thiersch. 2001. Remarks on parentheticals. In Progress in Grammar. Articles at the 20th Anniversary of the Comparison of Grammatical Models Group in Tilburg, eds. Marc van Oostendorp and Elena Anagnostopoulou. Utrecht: Roquade. http://www.meertens.knaw.nl/books/ progressingrammar/corver.pdf.

Deal, Amy Rose. 2009. The origin and content of expletives: evidence from "Selection". Syntax 12(4): 285-323.

Frampton, John, Sam Gutmann, Julie Legate, and Charles Yang. 2000. Remarks on "Derivation by Phase": Feature valuation, agreement, and intervention. Ms., Northeastern University and Yale University.

Hartmann, Jutta. 2005. Why there is(n't) wh-movement in there-constructions. In Linguistics in the Netherlands 2005, ed. Jenny Doetjes and Jeroen van de Weijer, 87-98. Amsterdam: John Benjamins.

Hazout, Ilan. 2004. The syntax of existential constructions. Linguistic Inquiry 35: 393-430.

Hoekstra, Teun. 1984. Transitivity; grammatical relations in government-binding theory. Dordrecht: Foris.

Hoekstra, Teun, and René Mulder. 1990. Unergatives as copular verbs; locational and existential predication. The Linguistic Review 7: 1-79.

Hornstein, Norbert. 1999. Movement and control. Linguistic Inquiry 30: 69-96.

Jaeggli, Osvaldo. 1986. Passive. Linguistic Inquiry 17: 587-622.

Koster, Jan. 1978. Why subject sentences don't exist. In Recent transformational studies in European languages, ed. Samuel Jay Keyser, 53-64. Cambridge, MA: MIT Press.

Koster, Jan. 1987. Domains and dynasties. Dordrecht: Foris.

Lasnik, Howard. 1999. Minimalist analysis. Malden: Blackwell.

Milsark, Gary. 1974. Existential Sentences in English. Doctoral dissertation, MIT. Bloomington, Indiana: Indiana University Linguistics Club.

Mohr, Sabine. 2002. German, Dutch and Icelandic - so similar and yet so different. Paper presented at Klausurtagung des GRK 609, Kleinwalsertal/Universität Stuttgart, June 20-23, 2002.

Moro, Andrea. 1997. The raising of predicates: predicative noun phrases and the theory of clause structure. Cambridge: Cambridge University Press.

Postal, Paul, and Geoffrey K. Pullum. 1988. Expletive noun phrases in subcategorized positions. Linguistic Inquiry 19: 635-670.

Reinhart, Tanya. 1983. Point of view in language-The use of parentheticals. In Essays on Deixis, ed. Gisa Rauh, 169-194. Tübingen: Narr.

Reuland, Eric. 1983. On the subject of nonargument subjects. In On the formal syntax of the Westgermania. Papers from the 3rd Groningen Grammar Talks (3e Groninger Grammatikgespräche), Groningen, January 1981, ed. Werner Abraham, 3-46. Amsterdam: John Benjamins.

Reuland, Eric. 1985. Representation at the level of Logical Form and the definiteness effect. In Grammatical representation, ed. Jacqueline Guéron, Hans Obenauer, and Jean-Yves Pollock, 327362. Dordrecht: Foris.

Roberts, Ian. 1985. The representation of implicit and dethematized subjects. Doctoral dissertation, USC. 
Rosenbaum, P.S. 1967. The grammar of English predicate complement constructions. Cambridge: MIT.

Ross, John R. 1973. Slifting. In The formal analysis of natural languages. Proceedings of the first international conference, ed. Maurice Gross, Morris Halle, and Marcel-Paul Schützenberger, 133169. The Hague: Mouton.

Ruys, E.G. 2003. Chomsky on there: MPLT and beyond. Ms., Utrecht University.

Safir, Ken. 1985. Syntactic chains. Cambridge: Cambridge University Press.

Schütze, Carson T. 1999. English expletive constructions are not infected. Linguistic Inquiry 3: 467-484.

Schwartz, Arthur. 1972. Constraints on movement transformations. Journal of Linguistics 8: 35-85.

ten Have, Erna. 2004. PP en QR in NL. Paper presented at TiN-dag, Utrecht, Feb 7, 2004.

van Riemsdijk, Henk. 1978. A case study in syntactic markedness; the binding nature of prepositional phrases. Lisse: Peter de Ridder Press.

van Zoelen, Albert. 2005. TEC-talen en niet-TEC-talen: wat is het technische verschil? Over transitieve, intransitieve, onaccusatieve en passieve expletiefconstructies. Unpublished MA thesis, Utrecht University.

Vikner, Sten. 1995. Verb movement and expletive subjects in the Germanic languages. Oxford: Oxford University Press.

Williams, Edwin. 1994. Thematic structure in syntax. Cambridge, MA: MIT Press.

Zaenen, Annie. 1993. Unaccusativity in Dutch: Integrating syntax and lexical semantics. In Semantics and the Lexicon, ed. James Pustejovsky, 129-161. Dordrecht: Kluwer. 